\title{
COMMENTS
}

\section{NON-MAJOR-PARTY CANDIDATES AND TELEVISED PRESIDENTIAL DEBATES: THE MERITS OF LEGISLATIVE INCLUSION}

\author{
KEITH DARREN EISNER†
}

\begin{abstract}
Historically, [minor-party and independent] candidates have been fertile sources of new ideas and new programs, and provide opportunities for the American public to enter into a diverse and open dialog[ue] on the critical issues of the day. These candidates often represent views held by large segments of the disenfranchised of our population, and their inclusion will surely stimulate discussion of substantive issues. . . . Including [significant] independent and minor party candidates is a critical aspect of [democratizing] the debates and broadening our national dialog[ue].

- Representative Timothy J. Penny, of Minnesota's Democrat-Farmer-Labor Party ${ }^{1}$
\end{abstract}

[National] campaigns [in our political system] serve other purposes besides electing particular candidates to office. They are also used to educate the public, to advance unpopular ideas, and to protest the political order, even if the particular candidate has little hope of election.

- Judge John H. Pratt ${ }^{2}$

That's the beauty of being a third party. ... You're not going to win anyway, so you can just go out and tell the truth.

- Sonia Johnson, 1984 Citizens-Party presidential nominee ${ }^{3}$

† B.A. 1989, Cornell University; J.D. Candidate 1993, University of Pennsylvania. A paper originally written for Professor C. Edwin Baker's Mass Media Policy class served as the foundation for this Comment. I am grateful to Professor Baker for both his guidance and wisdom, and to my Law Review colleagues for their able assistance. With love, I dedicate this Comment to my parents, and especially to my father, the best lawyer I have ever known.

137 CONG. REC. E397, E398 (daily ed. Feb. 4, 1991).

${ }^{2}$ Common Cause v. Bolger, 512 F. Supp. 26, 32 (D.D.C. 1980), aff', 461 U.S. 911 (1983).

${ }^{3}$ T.R. Reid, Feminism Propels Citizens Party's Nominee: Sonia Johnson Contends Women in This Society Are Born 'Behind Enemy Lines,' WASH. POST, Oct. 29, 1984, at A5. 


\section{INTRODUCTION}

The nationally televised presidential debate occupies a role of singular significance in American politics. In sheer scope of importance, ${ }^{4}$ in extent of audience interest ${ }^{5}$ and breadth of media coverage $e^{6}$, the debate stands alone among campaign events. The charges critics have leveled against debates are by now commonplace: they are superficial; ${ }^{7}$ they emphasize image over substance; ${ }^{8}$

${ }^{4}$ See Debates Gave Voters Information, Insight About Candidates, CHRISTIAN SCI. MONITOR, Oct. 23, 1984, at 3 [hereinafter Debates Gave Voters] (noting that debates can have more voter impact than any other single candidate appearance during the latter stages of a campaign). Rep. Edward Markey of Massachusetts has contended that debates are "an integral part of electing our President.... [they are] an important part of our democratic process." 137 CONG. REC. E643 (daily ed. Feb. 26, 1991). Rep. Penny has argued that "[p]residential debates can make a profound contribution to the health of our democracy, for they have become an important forum for exposing citizens to the ideas of candidates running for national office." 137 CONG. REC. E397, E398 (daily ed. Feb. 4, 1991).

${ }^{5}$ See, e.g., 137 CONG. REC. E643 (daily ed. Feb. 26, 1991) (remarks of Rep. Markey) (noting that "nearly $50 \%$ of American households with televisions tune in to Presidential debates"); 137 CONG. REC. E397, E398 (daily ed. Feb. 4, 1991) (remarks of Rep. Penny) (noting that in 1988, 160 million people watched the Bush-Dukakis debates); David J. Lanoue \& Peter R. Schrott, The Joint Press Conference: The History, IMPaCT, AND Prospects of American Presidential Debates 1 (1991) (noting estimates that almost $90 \%$ of American adults watched at least one of the Kennedy-Nixon debates in 1960); LEE M. MITCHELL, WITH THE NATION WATCHING: REPORT OF THE TWENTIETH CENTURY FUND TASK FORCE ON TELEVISED PRESIDENTIAL DEBATES 42 (1979) ("The [1960 and 1976] debates have placed the candidates before the largest audience in history."); Ellen Goodman, Don't Let the Parties Downplay TV Debates, NEwSDAY, Aug. 9, 1988, at 56 (noting that in 1984 nearly 125 million Americans watched the Mondale-Reagan and Bush-Ferraro debates).

The 1992 Bush-Clinton-Perot debates attracted the largest audiences in debate history: 87 million people watched the first debate, 92 million the second, and 91 million the third. See Ben Kubasik, Another 90 Million Saw Third Debate, NEwSDAY, Oct. 21, 1992, at 17 .

${ }^{6}$ See LANOUE \& SCHROTT, supra note 5, at 2 ("The media . . . continue to regard debates as events of significant magnitude. For all their complaining about the limits of the format and the overly rehearsed candidate presentations, journalists expend large amounts of ink and airtime on the debate story.").

${ }_{7}$ See, e.g., Walter Shapiro, What Debates Don't Tell Us, TIME, Oct. 19, 1992, at 32 (noting "the inherent problem with presidential debates: what is remembered is the theatrics, the contrived drama, the carefully rehearsed sound bites"); Tom Wicker, Who Needs Debates?, N.Y. TIMEs, Sept. 6, 1988, at A23 ("Modern televised Presidential debates ... have been full of demagoguery, misinformation and exaggeration, with 'victory' being claimed for such trivial reasons as Gerald Ford's misunderstanding of a question on Poland or Ronald Reagan's amiable jokes about his own age."). The 1960 Kennedy-Nixon debates demonstrated that "there was more to debating on television than just talking issues." Never-ending Debate (MacNeil/Lehrer Newshour, Aug. 10, 1987), available in LEXIS, Nexis Library, Script File [hereinafter MacNeily Lehrer Newshour] (remarks of Roger Mudd).

${ }^{8}$ See, e.g., MrTCHELL, supra note 5, at 44-45 ('In determining who had 'won' the 
they foster the trivialization of politics and elevate the office of the presidency at the expense of the political parties; ${ }^{9}$ and they divert the public from the other aspects of the campaign. ${ }^{10}$ Although these charges are not without validity, most contemporary commen-

[1960 Kennedy-Nixon] debates, the most important determinant seemed to be the 'style' of a candidate ... and his personality."); How to Ensure Presidential Debates, CHI. TRIB., Feb. 18, 1987, at 15 (noting complaints that the debates "emphasize personality and telegenic attractiveness rather than substance and character"); Shapiro, supra note 7, at 33 (lamenting that "[1]ost in the spin control are those rare insightful moments that foreshadowed what a would-be President actually will do in office, the crises he will face, and ... the fateful errors that are to be his legacy"); Wicker, supra note 7, at A23 (commenting that debates are "campaign appearances, not seminars on the issues"). But see MrTCHELL, supra note 5, at 45 (arguing that even conveying an image has a legitimate role in a presidential election, "especially where the image conveyed is a reasonably accurate reflection of the candidate. The ability to project a television image allows a candidate to overcome inaccurate public perceptions of the candidate or even deep-seated biases"). See also 137 CoNG. REC. E643 (daily ed. Feb. 26, 1991) (remarks of Rep. Markey) ("Viewers know that regardless of how well coached or prepped a candidate may be prior to taking the stage, he or she is alone, unfiltered, and eye-to-eye with the voter once the debate begins. And that's the way voters like to judge candidates."); KATHLEEN HALL JAMIESON \& DAVID S. BIRDSELL, PRESIDENTIAL DEBATES: THE CHALLENGE OF CREATING AN INFORMED EleGTORATE 15 (1988) (arguing that debates are "powerful vehicles both for informing and for exposing an oftenmaligned but nonetheless important characteristic of candidates disparaged as image"); LANOUE \& SCHROTT, supra note 5, at 134 (proposing that "if candidate images are, aside from partisanship, the single strongest predictor of presidential voting behavior, an event that alters these images must be considered electorally consequential").

Debate commentator Norman Cousins has also observed:

No amount of TV makeup can change the way a man's eyes move, or the way his lips are drawn under surges of animus or temper. When the camera burrows into a man's face, the fact that some wrinkles may be covered up by pancake makeup is not as important as the visibility of the emotions that come to the surface. The strength of the TV debates derives less from what is hidden than from what is impossible to conceal.

MrTCHELL, supra note 5, at 45-46. Indeed, "[w] hatever their weaknesses, the debates [are] the only time during ... presidential campaigns that the two major candidates [appear] together side by side and under conditions that they [do] not control." Id. at 5 .

${ }^{9}$ See How to Ensure Presidential Debates, supra note 8, at 15. See generally THEODORE J. Lowi, The Personal President: Power INVEsted, Promise UNFUlfilled (1985) (arguing that the advent of a plebiscitary presidency has resulted in unrealistic expectations that render contemporary presidential success a virtual impossibility). By personalizing the candidates, the debates imbue the presidential aspirants with a sense of power and importance arguably disproportionate to their true role, thereby drawing attention to individuals rather than issues. See Robert J. Samuelson, Bottom Line on the Issues, NEWSWEEK, Oct. 19, 1992, at 29 ("Every election creates the illusion that the president deserves full credit or blame for the economy.... [T] [he personalization of policy .. .obscures [the President's] modest impact.").

${ }^{10}$ See How to Ensure Presidential Debates, supra note 8, at 15. 
tators nonetheless agree that debates $d o$, in fact, inform the public about issues. ${ }^{11}$ In addition, they serve the important functions of revealing candidate stances; ${ }^{12}$ guiding the public in its vote; ${ }^{13}$ and reinforcing the electoral choices people have already made. ${ }^{14}$

${ }^{11}$ See, e.g., LANOUE \& SCHROTT, supra note 5, at 145 (" $[\mathrm{M}]$ ore information is provided by presidential debates than by most other common purveyors of persuasive messages, including candidate speeches and political advertisements."); MITCHELL, supra note 5, at 46 ("Televised presidential debates do indeed, notwithstanding charges to the contrary, convey information about campaign issues."); Jack W. Germond \& Jules Witcover, Are Presidential Debates Inevitable?, NAT'L J., May 19, 1990, at 1244 ("With the number of distorted TV campaign commercials steadily increasing, the presidential debates become a more essential ingredient than ever for an informed electorate.").

Two prominent observers are convinced of the impact of debates:

The social pressure to take a sustained view of both candidates creates a

climate more conducive to political learning than any other which the typical voter will seek or chance upon.

In a campaign season chock full of spot ads and news snippets viewers

turn to debates to provide sustained analysis of issues and close comparisons

of candidates. "Debate" has become a buzzword for "serious politics."

JAMIESON \& BIRDSELL, supra note 8, at 5 .

${ }^{12}$ See 137 CoNG. REC. E397 (daily ed. Feb. 4, 1991) (remarlss of Rep. Penny) ("Presidential debates . . . have become an important forum for exposing citizens to the ideas of candidates running for national office."); LANOUE \& SCHROTT, supra note 5 , at 131 (noting that voters see debates "as a significant source of information about the candidates and their issue positions"); MITCHELL, supra note 5, at 21 (debates serve "as a useful check on the candidates' own versions of their ... positions as presented in candidate-produced commercials or by other stagecraft").

${ }^{13}$ See, e.g., LANOUE \& SCHROTT, supra note 5, at 131 (noting that voters "view debates as often decisive to their own choices of how to vote"); id. at 145 ("[D]ebates do seem to provide the opportunity to enhance voters' ability to choose rationally."); id. at 2 ("[D]ebates contribute to the factors that ultimately determine how viewers vote."); How to Ensure Presidential Debates, supra note 8, at 15 (noting that debates "provide an opportunity for voters to assess the candidates ... over an extended period of time, in a live broadcast, without the immediate filter of consultants and aides"); Marvin Kalb, Campaign Debates: Can They Be Saved?, USA TODAY, Sept. 22, 1992 , at 13A ("Every academic study shows that the presidential debates are crucially important moments in the campaign, when the people take a deep breath to watch, listen and make a final judgment on the next president of the United States."). Less knowledgeable or committed voters are drawn to debates because they may be interested in guidance and information. See LANOUE \& SCHROTT, supra note 5, at 121. For voters possessing limited information and few preexisting biases, the televised debate may actually have a direct and unmediated effect on candidate and issue evaluation. See id. at 136.

${ }^{14}$ See, e.g., LANOUE \& SCHROTT, supra note 5, at 15-16 ( ${ }^{\star}$ Debates . . . are more important for their ability to reinforce candidate and party preferences than to alter them."); MrTCHELL, supra note 5, at 47 (noting that debates are particularly effective in reinforcing or crystallizing voter predispositions, and this reinforcement can have an "important impact" on an election); Debates Gave Voters, supra note 4, at 3 ("[P]eople who were leaning toward one of the candidates tended to have their inclinations reinforced by the debates."). 
Not surprisingly, the debates also stimulate voter interest, ${ }^{15}$ a dynamic that may lead to greater voter participation. ${ }^{16}$ Lastly, debates are of symbolic importance, allowing the voters to engage in the political process through their connection to the candidates. ${ }^{17}$ In short, in an age in which the importance of media exposure for informing the electorate, amassing voter support, and waging a successful campaign is axiomatic, televised presidential debates matter. ${ }^{18}$

Because debates matter, significant third-party or independent candidates should be allowed to participate. The argument for including such candidates, however, cannot rest on their potential for garnering enough support to win a presidential election. ${ }^{19}$ Indeed, the electoral record of independent and third-party candidates $^{20}$ in the United States is one of "nearly total fail-

15 See 137 CoNG. REc. E643 (daily ed. Feb. 26, 1991) (remarks of Rep. Markey) ("The anticipation of nationally televised face-to-face meetings between candidates is a galvanizing force in the electoral process. The debates focus public attention [and] heighten voter interest. . . . This is an important part of our democratic process."); MITCHELL, supra note 5, at 5, 43 (discussing the dramatic interest in the election campaign and the candidates which followed the 1960 televised debates).

${ }^{16}$ See 137 CONG. REC. S2334, S2334 (remarks of Sen. Graham) (noting that debates foster a "mutuality between the candidate and the electorate, or the office holder and the citizen, that is needed for both to participate in the political process and for democratic government to endure. . . . [They are] a way of getting people involved [that] may bring Americans back to the polls"); $c f$. Bernard C. Barmann, Third-Party Candidates and Presidential Debates: A Proposal to Increase Voter Participation in National Debates, 23 CoLuM. J. L. \& Soc. PROBS. 441, 442 (1990) (arguing that the inclusion of third-party candidates in the debates will increase voter participation by forcing the electoral system to provide the public with information about third parties, thereby increasing the accountability of elected officials). But see MrTCHELL, supra note 5, at 43 (stating that "[i]t is unclear, however, whether this interest leads to a higher voter turnout at the polls" and noting that voter turnout after the 1960 debates was only marginally higher than in 1952 and 1956, and that the 1976 debates did not stop the subsequent downward decline in voter participation).

17 See infra notes 70-71 and accompanying text.

${ }^{18}$ See James Endrst, The Vote is In ... And Politics on Television Will Never Be The Same, HARTFORD COURANT, Nov. 4, 1992, at A6 ("[The 1992 debates were] a series of ratings winners that proved once and for all that American viewers are interested in something more than soundbites."); see also LANOUE \& SCHROTT, supra note 5, at 4 ("D]ebates are often quite influential."); How to Ensure Presidential Debates, supra note 8 , at 15 (" $[\mathrm{P}]$ residential debates make an important contribution to the quality of the campaigns.").

${ }^{19}$ This is true despite the strong showing of Ross Perot in the 1992 election. See infra note 22 and accompanying text.

${ }^{20}$ For definitional purposes, this Comment will refer to presidential candidates not belonging to either the Democratic or Republican parties as independent candidates, on the one hand, and third-party or minor-party candidates, on the other. No distinction will be made between the terms third-party and minor-party. 
ure." 21 Given this record, as well as the apparent improbability that a third-party or independent candidate could win a presidential election in a two-party system-notwithstanding Ross Perot's 1992 performance ${ }^{22}$-participation in debates is unlikely to serve as a

21 ROBERT A. DAHL, POLITICAL OPPOSITIONS IN WESTERN DEMOCRACIES 34 (1966); see also Stephen J. Rosenstone et AL., THIRD PARTies IN AMERICA: Cittizen RESPONSE TO MAJOR PARTY FAILURE 229 (1984) ("Minor parties in America are condemned to their fate as third place finishers."). The electoral failure of third-party or independent candidates is perhaps best illustrated by the Bull Moose or Progressive party, "[t]he most popular modern third party," which garnered only $27 \%$ of the vote in 1912 despite featuring a former president, Theodore Roosevelt, as its candidate. See Howard Fineman, Throwing a Mighty Tantrum: The Lure of Third-Party Candidacies, NEWSWEEk, Apr. 27, 1992, at 28; see also Theodore J. Lowi, Toward a More Responsible Three Party System: The Mythology of the Two-Party System and the Prospects for Reform, 16 PS 699, 703 (1983) (noting that "an electorally based third party ... has not been tried seriously on a national scale since the Progressives tried it in 1912").

Given the political reality that every candidate elected to the presidency since 1848 has been a Republican or a Democrat, third-party and independent candidates are under no illusions about the likelihood of winning elections. They run, not because they expect to win, but rather because they view a candidacy as an opportunity to advance their causes. See ROSENSTONE ET AL., supra, at 188.

22 Clearly, no current discussion of televised presidential debates and non-majorparty candidates would be complete without reference to Ross Perot. Throughout this Comment then, the discussion will advert to Perot when his experience is relevant. His bizarre candidacy in the 1992 presidential election is a timely example of the important role third-party and independent candidates can play in contemporary America. Before withdrawing from the presidential race in the summer of 1992, Perot enjoyed a remarkable ground swell of support attributable both to a political zeitgeist disgusted with politics as usual, and a populace thirsting for alternatives. See Fineman, supra note 21, at 28 (reporting a Republican-sponsored survey revealing that three-quarters of Americans think that "the entire political system is broken" ). Yet though his credibility may have been strained by a campaign that could be euphemistically described as unorthodox, 19 million voters still cast ballots for him. See Steven A. Holmes, An Eccentric But No Joke, N.Y. TIMES, Nov. 5, 1992, at AI (calling Perot "a political neophyte who said and did enough bizarre things during the Presidential campaign to allow his critics to brand him as an eccentric or worse," yet who still managed a better showing than any third-party candidate since Teddy Roosevelt ran as the Bull Moose candidate more than 80 years ago).

At first blush, the considerable backing Perot garnered, the level of media attention lavished upon him, and voters' ready acceptance of him as a major player in the presidential race, would seem to refute much of this Comment's argument about the nearly insuperable obstacles significant minor-party and independent candidates face, and the resultant necessity of legislatively insuring their inclusion in televised presidential debates. Closer scrutiny, however, reveals Perot to be the exception that proves the rule. Perot is unique in the history of third-party candidacies: a billionaire political outsider-cum-media magnet who was a distinctly atypical third-party candidate. See Ronald E. Cohen, Looking Back on This Week's Campaign Trail, Gannett News Serv., Oct. 2, 1992, available in LEXIS, Nexis Library, GNS File (" $[T]$ he Texas tycoon has no precedent in American presidential politics-mounting a full-fledged, third-party, multi-million dollar populist candidacy a month before election day."). Absent the ability to bankroll one's campaign to the 
springboard to electoral victory for such candidates. ${ }^{23}$ Electoral success, however, is not the touchstone by which the importance of a third-party campaign should be measured. Through policy innovation $^{24}$ and the potential to influence the electoral outcome, ${ }^{25}$ through their assurance that major parties will be held accountable ${ }^{26}$ and that disaffection with the two-party structure will be channeled into voter participation rather than a rejection of the political process, ${ }^{27}$ third-party and independent candidates play a vital role in the American political process, a role independent of electoral success.

This Comment will articulate justifications for the inclusion of significant minor-party or independent candidates in televised presidential debates. Minor-party participation in debates would allow such parties better to fulfill the historically crucial roles they play in our democracy. ${ }^{28}$ In addition, enhanced third-party or independent candidate participation would improve the debates,

tune of 60 million dollars, see Irwin Arieff, World Welcomes Clinton and His "New Beginning, " Reuters, Nov. 4, 1992, available in LEXIS, Nexis Library, Reuter File, a third-party or independent candidate would find the impediments to informing the voters and enriching the political dialogue-to say nothing of attracting votes-daunting. See The Wild Card, NEwSWEEK, Apr. 27, 1992, at 25 (noting that "a brash billionaire can well afford to rush in where ordinary politicians fear to tread"). In fact, juxtaposition of the Perot phenomenon with the plight of a conventional third-party or independent candidate dramatically underscores this Comment's thesis.

${ }^{23}$ The claim of one minor-party candidate, who asserted that "if I had been involved in the debates ... I would have gotten millions of votes," thus seems spurious. Garry Sturgess, Nonpartisan or Bipartisan?: Candidate: Presidential Debate System is Illegal, LEGAL TIMES, July 1, 1991, at 2 (statement by New Alliance Party candidate, Lenora Fulani, referring to her 1988 presidential bid). Although participation in debates would certainly render third-party candidates, and thus third parties, more competitive, it would on its own neither enable minor parties to surmount the many institutional obstacles confronting them, nor transform the twoparty system into a system in which third parties could compete on equal footing with Democrats and Republicans.

${ }^{24}$ See infra text accompanying notes 40-52.

${ }^{25}$ See infra text accompanying notes 53-59.

26 See infra text accompanying notes 60-64.

27 See infra text accompanying notes 65-68.

${ }^{28}$ In the words of Chief Justice Earl Warren:

All political ideas cannot and should not be channeled into the programs of our two major parties. History has amply proved the virtue of political activity by minority, dissident groups, who innumerable times have been in the vanguard of democratic thought and whose programs were ultimately accepted. Mere orthodoxy or dissent from the prevailing mores is not to be condemned. The absence of such voices would be a symptom of grave illness in our society.

Sweezy v. New Hampshire, 354 U.S. 234, 250-51 (1957). 
providing benefits to the electorate as a whole. ${ }^{29}$ This Comment will argue that inclusion could be best accomplished through the legislative process, by making the receipt of federal campaign matching funds contingent on participation in debates in which significant national third-party and independent presidential candidates appear. ${ }^{30}$

Part I of this Comment discusses the many important roles third parties play in our governmental system. Part II provides a brief overview of the considerable structural, political, and legal barriers third-party and independent candidates face as they endeavor both to amass voter support and to inform the electorate. From the single-member-district plurality system to federal campaign funding laws tilted to benefit the major parties, and from ballot-access restrictions to the omnipresent threat of being co-opted or delegitimized, third parties continually struggle for their very survival. These already substantial impediments are exacerbated by the socializing force of the two-party system and by media discrimination.

Part III discusses how exclusion from televised presidential debates harms significant third-party and independent candidates, and how inclusion would result in better third parties and better debates. Exclusion frustrates third parties' effective fulfillment of their roles, further delegitimizes them, and fosters the deterioration of the symbolic value such parties hold for their supporters. These effects could ultimately lead to their supporters' political nihilism and a consequent drop-off in voter participation. Inclusion, in contrast, helps legitimize third parties, ${ }^{31}$ enabling them better to influence the political agenda. Inclusion would be more than a largely symbolic gesture: it promises to stimulate voter interest while concretely improving debates both by reducing major-party opportunities to manipulate them, ${ }^{32}$ and by encouraging a fuller discussion of the relevant issues of the day. ${ }^{33}$

${ }^{29}$ See JAMIESON \& BIRDSELL, supra note 8, at 16 (asserting "that improved debates can strengthen the political process").

${ }^{30}$ For a discussion of the criteria that may be used in determining who qualifies as a "significant" third-party or independent candidate, see infra notes 184-229 and accompanying text.

31 Ross Perot's inclusion in the 1992 debates, for example, was an undeniable boon to his campaign. See David Firestone, Perot's Impressive Loss, NewsDaY, Nov. 4, 1992, at 29 (noting that Perot's impressive debate performance buoyed his campaign).

32 For contemporary examples of major-party attempts to manipulate the debate format, see infra notes 115-16, 196-200 and accompanying text.

${ }^{33}$ The late inclusion of Ross Perot in the 1992 presidential debates is a timely, if 
In Part IV, this Comment examines the inadequacy of recent judicial responses to third-party requests for inclusion in nationally televised debates. Three times in the past five years third-party candidates have petitioned federal circuit courts to intervene on their behalf; three times circuit courts of appeal have, on different bases, turned a deaf ear to these entreaties. ${ }^{34}$ Now, one thirdparty candidate's recent judicial effort, apparently reprising the substance of earlier litigation, seems poised to snake its way through the federal courts. ${ }^{35}$ Regardless of these cases' outcomes, however, the judiciary is an inappropriate vehicle for assuring the inclusion of such candidates in the presidential debates. To be practicable, such inclusion must be based on a consideration of political realities, on the weighing of societal costs and benefits, and on the finely tailored judgments that are the peculiar province of the legislature.

Finally, Part V of this Comment discusses three recent legislative initiatives which would institutionalize presidential debates by making the receipt of certain federal campaign funds by the majorparty candidates contingent on their participation in such debates. This section will first analyze the constitutionality of such proposals,

imperfect, example. Only from a sufficiently historical perspective will analysts be able to assess Perot's complex impact on the debates. At this stage, however, we can safely assert that just by stimulating public interest in the debates, and by honing in on the deficit issue, Perot enlivened the dialogue. Perot's late and unexpected reentry into the presidential race, however, meant that he was captive to the formats and requirements already hammered out by the two major candidates without a nonmajor-party candidate's presence or interests in mind. See, e.g., Michael K. Frisby, Highly Focused Debate Plan is Seen, Boston GloBe, Oct. 3, 1992, at 6 (noting that though Perot was invited to the debates, he was not allowed to alter any of the arrangements the two major parties had negotiated); Michael Kranish, As Debate Nears, Camps Weigh Choice of Joumalists, BOSTON GLOBE, Oct. 7, 1992, at 13 (noting that Perot's campaign was given no say about which journalists would participate in the debates). Additionally, the unusual nature of his candidacy characterizes him as something less than the apotheosis of the issue-oriented third-party candidate who attempts to shift the focus of the two major-party candidates to her own agenda. See Fineman, supra note 21, at 28. ("Most [third-party candidates] have been sore losers who stormed out of their party to champion a specific issue or to defend a region or class. Perot's calling card is an attitude, not an ideology-and he's intriguing to all walks."). Thus, Perot's unique status meant he was not ideally suited to enrich the debate or dialogue; he did so, however, nonetheless.

${ }^{34}$ See Fulani v. Brady, 935 F.2d 1324 (D.C. Cir. 1991) [hereinafter Fulani II], cert. denied, 112 S. Ct. 912 (1992); Fulani v. League of Women Voters Educ. Fund, 882 F.2d 621 (2d Cir. 1989) [hereinafter Fulani I]; Johnson v. FCC, 829 F.2d 157 (D.C. Cir. 1987); see also infra notes $122-62$ and accompanying text.

${ }^{35}$ See Fulani v. Brady, No. 92 Civ. 7182 (SWK) (S.D.N.Y. Oct. 9, 1992) [hereinafter Fulani III]. 
concluding that the weight of Supreme Court precedent militates in favor of a finding of constitutionality. Turning to the substance of the bills, this Comment urges that the first proposal is problematic because it contemplates the participation of only the two major parties. Furthermore, the second is flawed because, although it insures the inclusion of all candidates who meet certain objective criteria, it allows the perpetuation of the current bipartisan sponsorship of the debates by the two major parties. Such sponsorship surely is not in the best interest of those qualified third-party or independent candidates clambering for inclusion. In contrast, the third proposal requires nonpartisan sponsorship and includes realistic criteria that would enable significant non-major-party presidential candidates to participate in these fora. This Comment analyzes the third proposal, concluding that it should be adopted because it represents the best hope of providing for the presence of more than just two candidates in presidential debates.

Six elections since 1960 have been the occasion for presidential debates. ${ }^{36}$ These debates have been attended by considerable discussion about debate format, financing, timing, and frequency. ${ }^{37} \mathrm{~A}$ detailed examination of these issues is beyond the scope of the present inquiry. Rather, this Comment advocates reformation of the presidential debate system to encourage broader participation of minor-party candidates as an important and useful first step in debate reform. Additional substantive and structural change, a necessary second step in the improvement of presidential debates, will naturally flow from, and can only be built upon, such fundamental reform. ${ }^{38}$

${ }^{36}$ After the four Kennedy-Nixon debates in 1960, both Lyndon Johnson and Richard Nixon refused to engage in debates, resulting in a 16-year interim before Carter debated Ford in 1976. See LANOUE \& SCHROTT, supra note 5, at 16-17. Televised presidential debates have been held in every election since, with Carter debating Reagan and Reagan debating Anderson in 1980, Reagan debating Mondale in 1984, Bush debating Dukakis in 1988, and Bush, Clinton, and Perot debating each other in 1992. See id. at 24-43; Kubasic, supra note 5, at 17. With the exception of the 1980 debate between Republican nominee Ronald Reagan and independent candidate John Anderson, and the Bush-Clinton-Perot debates in 1992, third-party candidates have been excluded from presidential debates. See Barmann, supra note 16, at 442 n.8.

37 The major-party candidates invariably haggle over the elaborate details of the rules of engagement. See Goodman, supra note 5, at 56; Evans and Novak: Transcript \#127, at 10 (CNN television broadcast, Aug. 22, 1992) (remarks of Charles Black, Bush Campaign Senior Advisor) ("[T]here's usually a deadlock about [debates]. . . . But these things work out. It's like any other negotiation.").

${ }^{38}$ For a useful discussion of some recent proposals for substantive reform of 


\section{The Role of Third Parties}

[O]ur political system needs other parties to keep the major parties honest, to force the major parties to think about ideas they would normally disavow out of hand, and to bring into the system those people who feel they have no particular stake in the process any more. Strong, as opposed to weak, minority or alternative parties will be like yeast in the bread of American politics. $^{39}$

The most obvious and.concrete role third parties serve is that of policy innovators. ${ }^{40}$ The direct election of senators, women's suffrage, and the graduated income tax were all issues that third parties espoused first, ${ }^{41}$ as were railroad regulation, high standards for civil service, and the encouragement of both labor unions and cooperatives. ${ }^{42}$ Third parties occasionally shape the course of American politics, ${ }^{48}$ even altering the political agenda when the major parties have ignored issues and options. ${ }^{44}$ The position of a third-party or independent candidate-that of an outsider, fringing the American body politic-accounts in large measure for her ability to serve as a wellspring of policy initiatives. As one writer, recounting the 1980 presidential race and that John Anderson's positions were at once bolder and more innovative than those of Ronald Reagan, explained: "[S]uch is clearly the luxury of a candidate with little to lose. ${ }^{n 45}$

Ironically, just as it is true that "[w] hen the major party leadership continues to focus on an increasingly irrelevant agenda,

debates, see JAMIESON \& BIRDSELL, supra note 8, at 194-221.

39 Arthur Unger, Bill Moyers-"conscience of American TV?, CHRISTIAN SCI. MONITOR, Oct. 31, 1980, at 19 (quoting Bill Moyers).

10 The goal of policy innovation is one quite separate from that of electoral success. Many third-party and independent candidates run not to win, but to draw attention to the single issue for which their candidacies stand. For example, Sonia Johnson, a 1984 Citizens Party candidate for president, was candid about her use of the party as a vehicle for her feminist ideology. See Reid, supra note 3, at A5.

11 See ROSENSTONE ET AL., supra note 21, at 8.

42 See MTTCHELL, supra note 5, at 84.

43 See id. at 9.

14 See Anderson v. Celebrezze, 460 U.S. 780, 794 (1983) ("Historically political figures outside the two major parties have been fertile sources of new ideas and new programs; many of their challenges to the status quo have in time made their way into the political mainstream."); ROSENSTONE ET AL., supra note 21, at 8.

45 LANOUE \& SCHROTT, supra note 5, at 25-26; see also ROSENSTONE ET AL., supra note 21, at 222-23 (arguing that when major parties are unable or unwilling to deal with new issues, even those which concern a substantial portion of the electorate, minor parties can play a significant role). 
third parties become an important voice of change, ${ }^{\mathbf{4 6}}$ it is also true that the policy innovation responsible for a third party's temporary popularity becomes the instrument of its demise. When a minor-party attracts substantial backing, one or both major parties, anxious to capitalize on the third party's popularity and win over new supporters, seizes the minor party's ideas as its own. ${ }^{47}$ And once a minor party's platform has been adopted by a major party, the minor party's raison d'être is often extinguished, as is its viability. ${ }^{48}$

The success of these third-party policy innovations, then, is largely a function of major-party efforts to co-opt minor-party support. The gains thus realized by the disadvantaged in our society are due less to the democratic nature of our political system than to the use of a suddenly popular issue by one major party as a "brickbat" against the other. ${ }^{49}$ These policy innovations are also

${ }^{46}$ ROSENSTONE ET AL., supra note 21, at 222-23.

47 See id. at 8. Major-party response to Perot's initial withdrawal from the 1992 presidential race dramatized how minor-party support is assimilated. Both the Republican and Democratic campaigns solicited the support of Perot's backers immediately after his withdrawal, with each side claiming that its platform was similar in important respects to Perot's, and could better accommodate the concerns of his followers. See Steven Heilbronner, Clinton, Bush Race for Perot's Army, UPI, July 6, 1992, available in LEXIS, Nexis Library, UPI File (noting that Bush and Clinton "scrambled ... to present themselves as the natural heirs of Ross Perot's supporters, signaling an intense contest for the disenchanted voters"). After Perot's re-entry, the Clinton camp skillfully endeavored to adopt Perot's strident anti-governinent, antipolitics-as-usual stance. As one reporter noted a scant eight days before the election:

Mr. Clinton launched no . . specific attack on Mr. Perot or his proposals.

Instead, he used a classic Clinton campaign tactic-appropriating elements

of his opponent's most effective pitch-to tell voters he is on their side

against the Washington insiders who he said have claimed the White House.

Gwen Ifill, Despite Perot Surge, Clinton Keeps Sights on Bush, N.Y. TIMES, Oct. 26, 1992, at A14; see also Robin Toner, Handling Perot: A Very Delicate Affair, N.Y. TIMES, Oct. 26,1992 , at $A 1$ (noting that "the 1992 Presidential campaign [ended] as it began, with strategists in both major parties trying to chart, quantify, defuse or turn to their advantage the mercurial candidacy of Ross Perot ${ }^{n}$ ).

${ }^{48}$ Thus, although one commentator's criticism that minor-party candidates generally have no long-term impact, and are akin to "shooting stars," is largely accurate, it misses the point. See LARRY J. SABATO, THE PARTY's JUST BEGUN 38 (1988). Although a major party's adoption of any aspect of a third-party or independent candidate's platform may demonstrate the extent of such a candidate's ability to contribute to the political process, the contribution is not inconsequential. Long-term political viability, on the other hand, seems less important than an ability to affect the current national dialogue.

49 See Gerald John Fresta, There Comes a Time: A Challenge to the Two PARTY SYSTEM 14 (1986); ROSENSTONE ET AL., supra note 21, at 224. 
co-opted to prevent erosion of major-party support. ${ }^{50}$ Periods of third-party strength indicate major-party failure to represent citizens' political demands, ${ }^{51}$ and the major parties are quick to get the message. ${ }^{52}$ Although the political dynamic of co-optation exposes a cynical reality of two-party politics, it nonetheless dramatizes a key function of minor parties: by raising issues which the major parties feel compelled to seize upon as their own, third parties serve as useful catalysts for policy change.

In some situations, third parties can even have a stake in affecting electoral outcome. ${ }^{53}$ As of 1980 , third parties controlled enough votes in the right states to have changed, at least theoretically, one-third of the electoral college results. ${ }^{54}$ As one historian notes, "[a] glance through American history would seem to indicate that [a vote for a third party] is probably the most powerful vote that has ever been cast. ${ }^{\text {} 55}$ A calculating third-party campaign-such as that of Dr. Lenora Fulani, ${ }^{56}$ whose asserted electoral strategy in 1988 was to cost Michael Dukakis the election by denying him ten percent of the black vote ${ }^{57}$-may be sufficiently

${ }^{50}$ See ROSENSTONE ET AL., supra note 21, at 224.

51 See id. at 4, 215.

52 See Lowi, supra note 21, at 703.

53 See ROSENSTONE ET AL., supra note 21, at 222.

$54 \mathrm{See} i d$. at 4 . This assessment predates the 1992 election.

55 John Hicks, The Third Party Tradition in American Politics, 20 MISs. VALLEY HIST. REV. 26, 26-27 (1933). But cf. FRESIA, supra note 49, at 200 (arguing that the challenge to a two-party system must come from the creation of a multi-party system, not from third parties, which either play minor roles in our two-party system or become mere appendages of the major parties). To say that a third party can affect an electoral outcome, however, is not to say that it usually does. Perot's support, for example, seemed to derive rather equally from both the Republican and Democratic camps. See R.W. Apple, Jr., The Economy Falters, A President Falls, N.Y. TIMES, Nov. 4, 1992, at A1, B5 (noting that exit polls indicated that Perot's support came from both parties, with slightly more people indicating they would have voted for Clinton if Perot had not made his late re-entry); Ronald Brownstein, Economic Concerns Fueled Clinton's Drive To Victory, L.A. TIMES, Nov. 4, 1992, at A1 (reporting an exit poll indicating that "Perot cut a broad swath down the center of the electorate ... [but] Perot's presence had no meaningful impact on the overall national voten $)$.

${ }^{56}$ The remainder of this Comment will allude, with some frequency, to Lenora Fulani and her past and present candidacies for president. Fulani, a recipient of federal matching funds for both the 1988 and 1992 campaigns, has engaged in protracted yet unsuccessful federal litigation to gain inclusion on the televised debates. As a case study of a third-party candidate with a colorable claim for such inclusion-a claim necessarily based on, and one that must be objectively assessed by, total funds raised and ballots accessed-Fulani's recent history is indispensable to a full and fair discussion of the topic at hand. The author wishes to stress, however, that nothing in this Comment should be deemed as an endorsement of Fulani, her party, or her views.

57 See Andrew Rosenthal, Independent Candidate Plays a Spoiler's Role, N.Y. TIMES, 
threatening to compel a major party to compromise with such a candidate or to co-opt her views. ${ }^{58}$ Obviously, the closer the race between the two major parties-and the broader the support a third party has-the greater the urge to compromise or co-opt. ${ }^{59}$

Third parties also play a crucial role in keeping the major parties accountable, ${ }^{60}$ and in shaping the programs the Democrats and Republicans pursue while in office. ${ }^{61}$ The full extent of the thirdparty role in shaping public policy is not always immediately apparent; third-party ideas often filter gradually into major-party programs. ${ }^{62}$ In many cases, however, the influence of third parties is more obvious and unmediated. ${ }^{63}$ The nettlesome presence of minor parties, then, is a subtle inter-election goad to major parties, who adopt their positions not out of an altruistic desire to represent minority viewpoints, but in order to put third parties out of business. ${ }^{64}$

Third parties also serve as conduits for the expression of discontent with the major parties. ${ }^{65}$ This role is crucial given the downward spiral in voter turnout in recent decades. ${ }^{66}$ By giving the disaffected a voice and a corresponding desire to take part in the political process, third parties encourage the electoral participa-

Oct. 26, 1988, at A23.

${ }^{58}$ See ROSENSTONE ET AL., supra note 21, at 224. Fulani, however, lacked sufficient voter support to have such influence.

${ }^{59}$ This point is aptly illustrated by the Democrats and Republicans promptly courting Perot's supporters following his abrupt abandonment of his quest for the presidency. See supra note 47.

${ }^{60}$ A significant third-party presence could "clarify the policies, programs and accountability of the two major parties." Lowi, supra note 21 , at 705.

61 See ROSENSTONE ET AL., supra note 21, at 222 (noting, for instance, the profound impact that George Wallace's candidacy had on the Nixon administration's civil rights policies). Ross Perot, for example, may prove a "useful catalyst" for forcing the Clinton Administration to confront the deficit issue. See . . As Third Parties Wait, USA TODAY, Nov. 4, 1992, at 18A; see also infra note 73.

${ }^{62}$ See, e.g., Daniel A. Mazmanian, ThiRd Parties in PResidential Elections 81 (1974) ("[M] ajor portions of the New Deal programs of Franklin Roosevelt are . . . attributed to the Progressive platforms of the preceding decades. ${ }^{n}$ ).

${ }^{63}$ See id.; see also supra text accompanying notes 40-42.

64 See ROSENSTONE ET AL., supra note 21 , at 221. 67.

${ }^{65}$ See id. at 5-6, 215. Again, the example of Perot proves fruitful. See infra note

66 See BUREAU OF THE CENSUS, U.S. DEP'T OF COMMERCE, STATISTICAL ABSTRACT OF THE UNITED STATES 1989, at 258 (109th ed. 1989) (table 433 showing that the percentage of the voting age population casting presidential ballots has consistently declined from $62.8 \%$ in 1960 to $50.2 \%$ in 1988); see also FRESIA, supra note 49, at 196 (noting that the "genuinely disaffected in a political system like ours" are likely to withdraw). 
tion of the disenchanted and insure that these marginal constituencies do not resort to less acceptable forms of protest, such as civil disobedience or withdrawal from the political process. ${ }^{67}$ This disillusionment is thus channeled from a general rejection of the American system of government to a protest against the two-party

${ }^{67}$ See id. at 26-27 (arguing that "movement politics" enables "those who are disenchanted with the rewards and the processes of the two party system ... to feel good about political participation"); ROSENSTONE ET AL., supra note 21, at 224 (suggesting that voters disaffected with the two major parties "might have to turn to less accepted forms of action" if the third-party route is closed off to them).

The coniemporary example of Ross Perot and his off-again, on-again candidacy, is illustrative. Through his candidacy Perot mobilized those voters disillusioned with two-party politics, and encouraged their participation in the political process during the 1992 presidential race. His supporters were the "perennially quiet constituencythe Great American Middle-[that] was coming to life, expressing its anger, discovering its strength," those citizens who were "solid, sane, decent and disgusted with politics as usual." Joe Klein, Perot's People: Second Thoughts, NEwSWEEk, Oct. 5, 1992, at 44, 44. "Perot became a blank screen on which millions of American voters could project their discontents, an empty vessel into which they could pour their hopes for a government that is free from partisan conflict and brokered compromise." Tom Morganthau, The Quitter: Why Perot Bowed Out, NewsweEk, July 27, 1992, at 28, 30. One commentator referred to him as "the inspirational commander of a new American revolution." Jonathan Alter, Perot's Last Casting Call, NEwsweEk, Oct. 12, 1992, at 44, 44. Even after Perot pulled out of the race, "thousands ... disillusioned with conventional politics, stayed in a movement that seemed to promise fresh approaches." Laurence I. Barrett, Remember Ross?, TIME, Sept. 21, 1992, at 25, 25. The support Perot retained or resurrected after his re-entry into the race was attributable to "the frustration and iconoclasm of people too proud to admit they'll succumb to a choice they consider dismal." Klein, supra, at 44.

Prior to the 1992 election, the alienation of the American voter was welldemonstrated by traditionally poor and consistently worsening voter turnout for presidential elections. See supra note 66 . The relatively high voter turnout in the 1992 presidential election thus illustrates the crucial role of third-party candidates like Perot in stimulating voter participation: credit for heightened voter interest is at least partially attributable to Perot, who was viewed as both a viable alternative to the major-party candidates and as a means of asserting "anger with the recession." See Richard Benedetto, Presidential Election: Voter Turnout, USA TODAY, Nov. 5, 1992, at 13A (noting estimates that Perot garnered nearly 20 million votes from the record 104 million cast, surpassing pre-election estimates and indicating that "he pulled many who might not have voted otherwise"); Robert Pear, 55\% Voting Rate Reverses 3-Year Decline, N.Y. TIMES, Nov. 5, 1992, at B4 ("Even more influential [than the recession] was Ross Perot's specific appeal to people who felt disenfranchised and had not voted in recent elections .... Mr. Perot caused the overall increase in turnout.").

Additionally, one can demonstrate that third-party candidacies increase voter participation by examining election statistics from previous years. In 1988, for example, nearly 900,000 voters cast their ballots for third-party candidates. THE WORLD ALMANAC AND BOOK OF FACTS 424 (Mark S. Hoffman et al. eds., 1992). Denied the alternative of a third-party or independent candidate and forced to pick between the two major-party candidates, many of these voters may have withdrawn from the political process and not voted. 
system, which an increasingly large segment of the American public has come to view with distrust or indifference. ${ }^{68}$ As one independent and minor-party presidential candidate commented: " $I$. . . see myself running against the two-party system that is tremendously unresponsive to most American people, and definitely to blacks. ${ }^{169}$

The existence of third parties also has symbolic significance, both from the standpoint of the individual voter and that of the political system in general. Although in terms of achieving direct results, a third-party vote may be viewed as futile, ${ }^{70}$ the individualized act of supporting a minor-party or independent candidate is not. To vote for a candidate who espouses an issue in which one fervently believes is to experience an empowerment that endures, despite the electoral failure of one's chosen candidate. Paradoxically, casting a ballot for a major-party candidate may provide no such sense of empowerment, particularly if that party ignores or disagrees with one on an issue of great personal significance.

The existence of the third-party presidential candidate is also a symbol of a democratized electoral process, one in which anyone

68 See Martin P. Wattenberg, The Decline of American Polttical Parties, 1952-1980 xv (1984) (arguing that the two major parties, "[o]nce the central guiding forces in American electoral behavior ... are now perceived with almost complete indifference by a large proportion of the population"); Lowi, supra note 21, at 702 (concluding that the "dramatic increase" in voters who refer to themselves as independents explodes the myth of the sufficiency of the two-party system); Kathryn A. Dunn, Note, Time for Faimess in the Presidential Electoral Process: Major and Minor Party Candidates in Competition, 6 J.L. \& Pol. 625, 630 (1990) (asserting that the decline "in major party affiliation indicates citizen dissatisfaction with the major-party candidates").

A particularly trenchant demonstration of current voter disgust with the two major parties is the fact that $50 \%$ of the $35 \%$ of the American electorate favoring Ross Perot in June 1992 indicated "they weren't voting for him so much as voting against the others. . . Voters are in a throw-the-bastards-out convulsion." Tom Mathews, President Perot?, NEwSWEEK, June 15, 1992, at 18, 18.

${ }^{69}$ Rosenthal, supra note 57, at A23 (quoting Lenora Fulani). Fulani has also stated that she plans to build "a genuine opposition force to the bipartisan antidemocracy known as the American electoral system." Carleton R. Bryant, Three More Toss Hats Into Presidential Ring, WASH. Times, Oct. 18, 1991, at A5.

${ }^{70}$ See ROSENSTONE ET AL., supra note 21, at 16-17 (stating that "[b]ecause citizens know third parties have very little chance of winning, they prefer not to waste their votes on them"); supra text accompanying note 55. Political scientist Theodore Lowi assails the "myth" that a vote for a third-party candidate is a wasted vote:

If the vote is for a candidate of a dissident party, it is a protest vote which can instill considerable anxiety in the leadership of the major parties. If the vote is for a candidate of a programmatic third party, a more substantive message is sent; and history shows that these messages are almost always received by leaders of the major parties.

Lowi, supra note 21, at 703. 
who can mobilize support can run for the presidency. More than a symbol, in fact, third parties prevent the Democrats and Republicans from irrevocably institutionalizing themselves as the only options with which voters are presented. In terms of fulfilling the symbolic function of third parties, their existence-rather than their electoral success-is the issue. ${ }^{71}$

The roles third parties play, then, serve as a means of encouraging reflective participation in the political system. This reflective participation broadens the limited range of political discourse inherent in the two-party system, ${ }^{72}$ thereby enriching the political process. ${ }^{73}$ The emerging visibility of third-party challenges since $1968^{74}$ underscores the promise third-party and independent candidates hold for broadening and enriching our national dialogue.

71 The presidency "stands as a living symbol of the nation." Therefore, the symbolic significance of the vote in a presidential election is correspondingly great. Dom Bonafede, It Does Make a Difference, NAT'L J., Nov. 8, 1980, at 1898. Third-party and independent candidates who bring the disenfranchised back to the voting booth help them to reaffirm their stake in both the electoral process and the concept of democracy.

${ }^{72}$ See FRESIA, supra note 49, at 124 (stating that "[u]nreflective participation in the two party system accepts [a] limited range of political debate and the policy options that flow from it").

${ }^{73}$ Perot again serves as a fruitful example. His late re-entry into the presidential race a mere 33 days before Election Day diminished his status as a serious presidential contender and diluted the full impact he might have had in broadening the political dialogue. Yet one could say that "by focusing attention on the deficit, Perot ... helped elevate the last stage of a race that might otherwise have been preoccupied entirely with mudslinging." Eleanor Clift \& Ginny Carroll, Perot: Pulling the Race Out of the Mud, NEWSWEER, Oct. 26, 1992, at 34, 34; see also Howard Fineman, Running Scared, NEWSWEER, Nov. 2, 1992, at 47, 48 (noting that a Clinton presidency will have to contend with Perot, "a sanctified, one-man Greek chorus on the evil of deficits"); Robin Toner, Perot Re-Enters the Campaign, Saying Bush and Clinton Fail to Address Government 'Mess, 'N.Y. TIMES, Oct. 2, 1992, at A1 (noting that after Perot reentered the race, "it was clear that [he] would affect the tone and the dynamic of the dialogue").

As election results poured in, analysts attempted to assess Perot's impact on the national dialogue. See, e.g., Tom Morganthau, Citizen Perot, NEwsweEk, Nov. 9, 1992, at 23, 28 (arguing that before Perot re-entered the race "there was little or no sign that George Bush and Bill Clinton were prepared to discuss [the] primal issues" of deficit control and generational fairness); Robin Toner, Clinton Wins Decisive Margin in the Voter Poll Across Nation After 12 Years of G.O.P. Rule, N.Y. TIMES, Nov. 4, 1992, at A3, B3 ("Mr. Perot's influence could be spied throughout the voting, not only in the salience of the deficit issue, but also in voters' attitude toward 'divided government.' Mr. Perot railed about 'gridlock' throughout the campaign, and the voters ... seemed to share his view ....").

74 See generally ScotT KeETER \& CLIFF ZUKIN, UNINFORMEd CHOICE 193 (1983) (noting arguments that third-party challenges have grown steadily "more credible"). 


\section{The BARRIERs FAcING THIRd PARTIES}

Despite the useful role third parties play in our political system, a host of structural, legal, and political barriers confront them at every turn. Structurally, the electoral college's plurality basis, with its winner-take-all format in each state, helps the Democrats and Republicans to win presidential elections. In plurality elections, party identification alone virtually assures that either the Democrats or the Republicans will emerge victorious. ${ }^{75}$ Faced with the prospect of narrowly losing in a state and getting nothing, a third party often succumbs to the pressure to moderate its agenda and coalesce with one of the major parties. ${ }^{76}$ This incentive to coalesce has constrained the viability of minor parties, often accounting for their inability to field presidential candidates in successive elections. ${ }^{77}$

${ }^{75}$ See Maurice Duverger, Duverger's Law: Forty Years Later, in ELECTORAL LAws AND TheIr Political Consequences 69, 69 (Bernard Grofman \& Arend Lijphart eds., 1986) (arguing that plurality voting tends to create and maintain two-party systems); see also FRESIA, supra note 49, at 202-03 (discussing the impact of plurality elections in general and the electoral college system in particular on third-party candidates); ROSENSTONE ET AL., supra note 21, at 16-17 (noting that a "candidate who comes in second or third in a particular state does not win a single electoral vote regardless of his percentage of the popular vote"). Ross Perot's performance in the 1992 presidential election is a case in point. Though he garnered better than $18 \%$ of the popular vote cast, he tallied zero electoral votes. See Carl M. Cannon, Clinton Victorious, PHILA. INQUIRER, Nov. 4, 1992, at A1.

The same effect obtains on the congressional level, where the single-member district system holds sway, in which voters elect only one representative from each district. Unlike European parliamentary proportional representation systems, the American system's winner-take-all outcome does not reward second- or third-place finishers, thereby discouraging minor-party participation. See Dunn, supra note 68, at 625. A minor-party supporter's pragmatic response is thus often not to vote her true preference, "but to vote for the lesser of two evils who has a chance of winning." FRESIA, supra note 49, at 202. A minor party's electoral futility at the congressional level sows the seeds for its failure at the presidential level: without support at the local level, a party stands slim chance of winning a presidential election. The singlemember-district plurality system could thus be considered the "single largest barrier to third party vitality." ROSENSTONE ET AL., supra note 21 , at 18 . A vote for thirdparty candidates-at either presidential or congressional level-is thus a leap of faith, a gesture of the most symbolic kind.

${ }^{76}$ See FrESIA, supra note 49, at 202 (noting that national third-party candidates with substantial backing feel tremendous pressure to bargain with one of the major parties, and offering the example of the People's Party in 1896).

77 See ROSENSTONE ET AL., supra note 21, at 18-19 (noting that most nationally based third parties survive only one election because they are unable to offer tangible benefits to their supporters, and documenting that, between 1840 and 1980, of the 45 individual minor-party or independent candidates receiving presidential popular votes in more than one state, $58 \%$ ran just once); see also Sara Fritz, Win or Lose, Perot 
Legal impediments to third-party presidential candidacies abound as well. The financial disparity between major- and minorparty coffers exerts an undemocratic influence on electoral politics as financially disadvantaged candidates are unable to communicate effectively their views and may never be able to stake a claim to legitimacy. ${ }^{78}$ This initial financial disparity is exacerbated by federal legislation that makes it far more difficult for independent or third-party candidates to obtain federal campaign funds than for major parties to do so. ${ }^{79}$ Ironically, these laws ensure that finan-

Changing Rules of Game, L.A. TIMEs, Oct. 18, 1992, at A1 (quoting political historian Richard Hofstadter's witticism that " $[t]$ hird-party candidates are like bees. Once they've stung, they die").

${ }^{78}$ See, e.g., Bonafede, supra note 71, at 1898 (arguing that third-party candidates, although "they had something worthwhile to say to the voters ... are denied an equal opportunity in terms of media coverage and government campaign financing"); $c f$. John M. Sylvester, Note, Equalizing Candidates' Opportunities for Expression, 51 GEO. WASH. L. REV. 113, 114 (1982) (urging congressional enactment of measures such as public funding for congressional campaigns, lower barriers to minor parties' qualification for public funding, and limited free access to the broadcast media for campaign expression).

The importance of public funding can be appreciated if one considers that in the 1992 election Clinton spent $\$ 78.8$ million in tax dollars, and Bush $\$ 76.4$ million. See Campaign Cost to Us: $\$ 173.7$ Million, AP, Nov. 2, 1992, available in LEXIS, Nexis Library, AP File [hereinafter Campaign Cost]. Ross Perot's reliance on his personal wealth also shows the importance of adequate financing. See Holmes, supra note 22, at Al ("To be sure, some of Mr. Perot's strength must be laid to his own formidable resources ... Mr. Perot could not have done what he did without his own tens of millions, as he would be the first to acknowledge."); Nightline (ABC television broadcast, Oct. 1, 1992) (statement of Sen. Tom Harkin) ("Quite frankly, anyone with a billion dollars could do what Ross Perot is doing.").

${ }^{79}$ See MITCHELl, supra note 5, at 84; Sylvester, supra note 78, at 127, 131 ( ${ }^{\text {As }}$ long as public financing advantages major-party candidates, it will encourage candidates to seek a major-party nomination.").

According to the Presidential Primary Matching Payment Account Act, 26 U.S.C. $\S \S 9031-9042$ (1988), in order to qualify for federal primary election matching funds, presidential candidates must raise $\$ 100,000$ in contributions from individuals, with at least $\$ 5000$ coming from contributions of no greater than $\$ 250$ each from residents in each of at least 20 states. See $i d$. $\S \S 9033$. Candidates must agree to spend no more than a specified limit in each state's primary campaign. See id. $\$ 9035$ (a). Furthermore, candidates must also keep certain records, and agree to submit those records for audit. See id. \$9033(b)(3), (4).

The most serious problems for non-major-party candidates are created by the Presidential Election Campaign Fund Act, see id. \$\$ 9001-9013. In order to be eligible for general election campaign funding, minor parties must be on the ballot in at least 10 states, see id. \$ 9002(2), a difficult feat for underfunded minor-party campaigns. See supra note 82-85. Minor-party candidates also must have obtained at least $5 \%$ of the national popular vote in the preceding presidential election, an unlikely accomplishrnent. 26 U.S.C. \$ 9002(7); see also STATISTICAL ABSTRACT OF THE UNITED STATES 1991, supra note 66, at 250 (tables 426 and 427 demonstrating the rarity of 
cial resources are least available to those candidates in direst need of them. The resultant small campaign war chests affect the ability of third-party or independent candidates to buy advertisements in the broadcast and print media, and to set up even the semblance of the far-flung campaign machines enjoyed by major-party presidential candidates. ${ }^{80}$ In short, electoral funding regulations diminish the likelihood that a minor party can significantly affect an electoral outcome, thereby enabling the major parties to be inattentive to minority concerns. ${ }^{81}$

Ballot-access laws are an additional legal impediment confronting minor-party or independent candidates. Because such laws differ from state to state, a minor-party or independent candidate wishing to place her name before the entire citizenry must leap fiftyone different bureaucratic hurdles, expending valuable time, energy, and resources while doing so. ${ }^{82}$ Although court decisions over the

minor-party candidates receiving more than $5 \%$ of the popular vote.) This requirement is particularly onerous for a first-time third-party or independent candidate, whose funding will not be forthcoming until after the election, and only if results show that she received at least $5 \%$ of the popular vote.

Moreover, the Federal Election Campaign Act, 2 U.S.C. $\$ \S 431-456$, articulates "stringent disclosure and filing requirements [that] impose a heavy burden on minor party campaigns," Dunn, supra note 68, at 643-44; 2 U.S.C. $\S \S 432-34$, and contribution limits are applied without regard to major-or minor-party status. See id. § 441(a); ROSENSTONE ET AL., supra note 21, at 26 (describing FECA as “a major party protection act").

${ }^{80}$ For example, Lenora Fulani ran her 1988 presidential campaign with only $\$ 2.5$ million, a budget smaller than that of most Senate campaigns. See Rosenthal, supra note 57, at A23. In 1988 Fulani was on the ballot in all 50 states, and received nearly $\$ 1$ million in primary election matching funds. See Sturgess, supra note 23, at 2. In 1992 , Fulani received about $\$ 2$ million in primary election matching funds. See The High Cost of Democracy; Taxpayers Fork Out \$173.7 Million, Reuters, Nov. 2, 1992, available in LEXIS, Nexis Library, Reuter File. Perot was not entitled to tax dollars since he funded his own campaign. See id.

81 See ROSENSTONE ET AL., supra note 21, at 224.

82 See id. at 20, 24; see also Dunn, supra note 68 , at 634 (noting that ballot-access laws impose a "heavy burden on minor-party candidates [forcing them] to expend a large portion of their scarce campaign resources on a project which is wholly unrelated to their primary function: gaining popular support for their campaign"). Ballot access can be attained by third-party or independent candidates only if they meet a state's requirements for collecting signatures on nominating petitions, or win the nomination of minor political parties who have permanent ballot status in that state or are poised to petition for a ballot position in the upcoming election, difficult prospects to contemplate for most third-party candidates. See Fulani v. League of Women Voters Educ. Fund, 684 F. Supp. 1185, 1187 (S.D.N.Y. 1988), aff'd, 882 F.2d 621 (2d Cir. 1989).

The ballot-access hurdle proved surmountable to 1992 independent presidential candidate Ross Perot, whose experience demonstrated just how much getting on the ballot in all 50 states and the District of Columbia in a short period of time can cost. 
past three decades have generally eased ballot-access restrictions, ${ }^{83}$ winning ballot access is still no mean feat. ${ }^{84}$ The money minorparty candidates spend on attaining ballot access is money that cannot be spent on advertising, voter education, and other expenses of a successful campaign. ${ }^{85}$ Thus, although such candidates may be able to gain ballot access, they do so only at great cost to their campaigns.

On a political level, third-party and independent candidates must struggle against constant pressure from the major parties, which seek both to delegitimize them and to co-opt their supporters. ${ }^{86}$ Major parties adjust their appeals first to accommodate and then to absorb the third parties that have emerged. ${ }^{87}$ The co-

Perot spent a whopping $\$ 18$ million in pursuit of this accomplishment. See What Does He Want?, NEwSWEEK, Sept. 28, 1992, at 16, 16. To say that only the richest-and rarest - of candidates could afford such a funding coup is to risk gross understatement.

83 See, e.g., Storer v. Brown, 415 U.S. 724, 735 (1974) (finding portions of California's ballot access law unconstitutional); Williams v. Rhodes, 393 U.S. 23, 81 (1968) (finding that an Ohio ballot access provision violated the equal protection clause of the Fourteenth Amendment); Fulani v. Krivanek, 1992 U.S. App. LEXIS 24723 (11th Cir., Oct. 5, 1992) (enjoining enforcement of a state statutory provision that prohibited minor-party candidates from availing themselves of a fee-waiver provision available to those qualifying for the ballot by petition). But see Dunn, supra note 68 , at 635 (noting that "a survey of legal challenges to ballot access laws indicates that judicial interpretations have yielded shifting decisions").

84 New Alliance Party presidential candidate Lenora Fulani, for example, had to amass more than 1.5 million signatures in 1988 to appear on the ballots in all $\mathbf{5 0}$ states and the District of Columbia. See Rosenthal, supra note 57, at A23. That feat, Fulani claimed, qualified her as a "major minor candidate." Id. Fulani, who garnered less than one percent of the vote in 1988, was on the ballot in 40 states in 1992. See FEDERAL ELECTION COMM'N, FEC APPROVES MATCHING FUNDS FOR 1992 PRESIDENTIAL CANDIDATES 2 (Oct. 30, 1992) [hereinafter FEC NEWS RELEASE] (news release listing presidential candidates on the general election ballots of each state and the District of Columbia).

${ }^{85}$ In 1980, for example, although John Anderson eventually appeared on all 51 general election ballots, his campaign had to spend more than half of the $\$ 7.3$ million it raised in a six-month period to enable him to do so. See ROSENSTONE ET AL., supra note 21, at 24. Anderson successfully challenged burdensome ballot-access laws, but prolonged litigation drained his limited campaign resources. See Dunn, supra note 68, at 639; see also Matthew Levie, Party Pooper: America v. Third Parties, NEw REPUBLIC, Jan. 6, 1992, at 13, 13 (noting that the Libertarians spent $\$ 2$ million dollars, or nearly one-fourth of the party's budget, to get candidate Ron Paul on 46 state ballots in 1988).

${ }^{86}$ See ROSENSTONE ET AL., supra note 21 , at $43-45$. The bright side of co-optation is that minor-party policy innovations are brought into the political mainstream by the major parties when those ideas either gain popularity among a significant number of voters or threaten to erode major-party support. See supra text accompanying notes 46-52. The dark side of co-optation, however, is the threat it presents to third-party survival. See supra text accompanying note 48.

${ }^{87}$ See ROSENSTONE ET AL., supra note 21, at 43-45; cf. FRESIA, supra note 49, at 97 
optation may even be anticipatory: major-party strategies, positions, and even choice of nominees often predict the response of potential third parties. ${ }^{88}$ The route for which some third-party and independent presidential candidates have opted is to attempt to make inroads within a major party by signing up for a primary. This solution too is fraught with the dangers of co-optation. ${ }^{89}$

The stranglehold the two major parties have on voters' preferences and voting patterns is also a result of socialization. Voters are socialized into a two-party norm, ${ }^{90}$ one that is reinforced daily by the portrayal of elections as two-party contests. ${ }^{91}$ To vote for a third-party candidate is not only a rejection of the two major party candidates; it is a self-conscious breach of the loyalty to the twoparty system that is a central feature of the American voter's political psyche. ${ }^{92}$

Finally, the media discriminates against third parties. ${ }^{93}$ Both publishers and broadcasters slight minor-party candidates, deeming

(" $[T]$ he realization that alternative agendas cannot be advanced unless alternative parties are represented compels third-party leaders to bargain with major party leaders in the hope that a watered-down version of their agenda will be accepted in exchange for their support.").

${ }^{88}$ See ROSENSTONE ET AL., supra note 21, at 222.

${ }^{89}$ Levie addresses the problem:

[Despite the fact that delegate selection rules have become more democratic since 1968,] the outsiders are almost always devoured by the mainstream. ... Under the illusion of greater openness lies the trap of cooptation. The Republicans still have "winner-take-all" primaries that favor the front-runner; the Democrats still have "superdelegates" who are likely to. Independent candidates are lured into the race only to be tripped up in the homestretch. Furthermore, primary voters [are] mostly the party faithful. The electorate most naturally sympathetic to an independent candidate is excluded from voting for her.

Levie, supra note 85, at 13.

90 American party politics is commonly referred to as a two-party system, a characterization supported by the dominance of Republicans and Democrats holding office at every level of government. See Dunn, supra note 68, at 631 (urging the relaxation of current barriers preventing "viable" minor-party candidates from effectively participating in the American political process). Despite the entrenchment of the current system, the institutionalization of the Democratic and Republican parties was not constitutionally preordained. "The Constitution does not assure the continuing existence of any particular party or guarantee that it will remain competitive." James W. Ceaser, Presidential Selection 345 (1979).

${ }^{91}$ See $i d$. at 279 (noting that "[t]he traditional political system' is identified entirely with a monopoly of the two-party system"); see also infra notes $93-99$ and accompanying text (discussing the media's role in perpetuating the two-party norm).

92 See CEASAR, supra note 90 , at 345.

93 See Levie, supra note 85 , at 13 (noting that the media focuses on "big" names and gives the upstarts short shrift). 
them unworthy of the attention given major-party candidates; ${ }^{94}$ at times the press even displays an overt hostility to third-party candidates. ${ }^{95}$ This result is particularly destructive to a third-party candidacy, for media coverage is an essential component of a successful campaign. ${ }^{96}$ It supplies the candidate with legitimacy and name recognition, which are both necessary to attract votes. ${ }^{97}$ The media exposure major-party candidates receive is an emolument of their status, amounting to a campaign subsidy. ${ }^{98}$ Media apathy begets a lack of voter awareness: "The political obscurity of most minor party candidates, their inability to publicize themselves as major party contenders can, and their neglect by the media mean that many voters simply do not have information on these candidates." ${ }^{99}$

94 See ROSENSTONE ET AL., supra note 21, at 35 ("Nearly two out of three newspaper editors thought that their readers had little interest in third-party candidates in 1980.").

${ }_{95}$ For example, the media initially extolled independent candidate John Anderson's 1980 bid for the presidency but turned against him when it became evident he could not win. See ROSENSTONE ET AL., supra note 21, at 33-34; cf. Jim Squires, A Collision Made in Heaven, NEwswEEk, Nov. 9, 1992, at 29, 29 (former Perot advisor characterizing the media's coverage of Perot as vindictive, and arguing that "[ $t$ ]he consensus of talking heads and pundit pens [was] that ... Perot [repeatedly] demonstrated temperament that disqualifies him from holding the nation's highest office").

${ }^{96}$ See Gregory P. Magarian, Fighting Exclusion From Televised Presidential Debates: Minor-Party Candidates' Standing to Challenge Sponsoring Organizations' Tax-Exempt Status, 90 MICH. L. REV. 838, 874 (noting that the mass media dominates many critical processes of elections, including setting agendas, legitimizing candidates, and determining candidates' public images).

97 See Dunn, supra note 68 , at 649 (noting that " $[\mathrm{w}]$ ithout sufficient media coverage, it is difficult if not impossible for minor party candidates to achieve the necessary degree of legitimacy" and that coverage of minor-party candidates by the media would beget further coverage, thereby diminishing their anonymity and fomenting increased public perception of them as "legitimate" candidates).

${ }^{98}$ Substantial media exposure is lavished upon major-party candidates at the expense of minor-party candidates. See Dunn, supra note 68, at 649 (stating that the alignment of most Americans with one of the two major parties is often deemed "sufficient justification for the news organizations' focus on major party candidates and neglect of minor party candidates").

${ }^{99}$ ROSENSTONE ET AL., supra note 21 , at 38 . Television coverage might be the most important form of media exposure in a presidential campaign, and the importance of television to a successful candidacy cannot be overestimated. "American politics and television are now so completely locked together that it is impossible to tell the story of one without the other." THEODORE H. WHITE, AMERICA IN SEARCH OF ITSELF: THE MAKING OF THE PRESIDENT, 1956-1980, at 165 (1982). Television has quite simply become "the dominant medium of political communication in the United States." See Dunn, supra note 68, at 647. Cf. Ronald K. L. Collins \& David M. Skover, The First Amendment in an Age of Paratroopers, 68 TEX. L. 
The myriad barriers, impediments, and constraints which confront third parties have thrust them into an ongoing crisis of legitimacy and have made "voting for a third party an act requiring unusual energy, persistence and desperation." 100 Third parties are trapped in a cycle of discouragement and futility, deemed unimportant because they receive little support or press coverage, and receiving little support or press coverage because they are deemed unimportant. ${ }^{101}$

REV. 1087, 1101 (1990) (lamenting the ascendancy of television's "sound-bite discourse" in presidential campaigns).

Third-party and independent candidates are uniquely vulnerable to the vicissitudes of television coverage. See MTTCHELL, supra note 5, at 84 (arguing that exclusion from equal time on television "threatens to obliterate [third-party candidacies] entirely"). In 1960, for example, after Congress temporarily suspended the "equal time" law and made it lawful for broadcasters to provide time to the two major-party candidates while excluding other candidates, the amount of time made available to minor-party candidates plunged by more than $90 \%$ from the levels of the preceding election. See id. Suspension of the equal time provision legitimized exclusion of minor-party candidates from the 1960 debates. See Dunn, supra note 68, at 651. Third parties like the Progressives may have flourished before the advent of television, but television has transformed politics. "Television viability [has become] the viability that matters. Television is American politics in the way that television is American sports." Robert MacNeil, Has Television Cast a Spell Over Politics?, TV GuIDE, June 28,1980 , at 5,5 .

The effect of this media bias is most dramatic in the context of televised debates: “'The two big parties have a monopoly on the media,' . . . and the debates, broadcast by all the networks, are the biggest media event." Ann Cooper, Tuning in on the Other 200 Presidential Hopefuls, NAT'LJ., Oct. 6, 1984, at 1885 (quoting Sonia Johnson, 1984 presidential candidate of the Citizens Party). Exclusion of minor-party candidates is not an oversight. Since 1976, debates have not been subject to the "equal opportunity requirement" of the Federal Communications Act, which required broadcasters providing time to one candidate for a public office to afford equal time to all other candidates. See ROSENSTONE ET AL., supra note 21, at 35 . Since the debates have been deemed exempt from the Act as "bona fide news events," the networks have no obligation to provide any free time for excluded third-party or independent candidates. See id. Additionally, the FCC has eliminated the Fairness Doctrine, which required broadcast media licensees to provide "a reasonable opportunity for the presentation of contrasting viewpoints on . . . issues." Syracuse Peace Council v. FCC, 867 F.2d 654, 655-57 (D.C. Cir. 1989) (describing the FCC's inquiry into the fairness and the wisdom of the doctrine, and its ultimate conclusion that the Fairness Doctrine "as a matter of policy, disserves the public interest"), cert. denied, 493 U.S. 1019 (1990).

${ }^{100}$ ROSENSTONE ET AL., supra note 21, at 27.

101 One writer has aptly summarized this effect:

Because citizens know third parties have very little chance of winning, they prefer not to waste their votes on them. Small parties become discouraged and either drop out or join with another party. At the same time, the system encourages the two major parties to try to absorb minor parties or prevent them from flourishing in the first place. 
The following section discusses how the exclusion of significant third-party and independent candidates from televised presidential debates compounds the already considerable obstacles that these contenders face, and prevents the debates from achieving their potential to perform a host of useful roles, not the least of which are informing the public, focusing attention on the election, and galvanizing voter participation. The inclusion of such candidates will make for better third parties and better debates. In both cases, the electorate will be the principal beneficiary.

\section{THE HARMS OF EXCLUSION AND THE MERITS OF INCLUSION}

\section{A. The Harms Of Exclusion}

If you're not on the debates, you're dead meat. ${ }^{102}$

Exclusion from a televised presidential debate-perhaps the single most important opportunity for a candidate to reach the voters ${ }^{103}$-is a paralyzing blow to the efforts of third parties to fulfill their crucial role. Excluded candidates are indeed "dead meat," but not because exclusion is the coup de grâce to their already meager hopes for electoral success. Rather, in an age when political significance and legitimacy are predicated largely upon television exposure, third-party and independent presidential candidates barred from televised debates have scant opportunity to bring alternative viewpoints to the public light, ${ }^{104}$ or to foil inces-

ROSENSTONE ET AL., supra note 21, at 16; see also id. at 39 ("Third party candidates also do poorly because most people think they will do poorly"). The fact that nearly $60 \%$ of all minor-party presidential candidates never run again a second time is thus unsurprising. Id. at 18; see also Dunn, supra note 68, at 649 (arguing that denying a campaign visibility "leads to a decrease in legitimacy, dwindling campaign contributions and ultimately obsolescence").

102 Wendy Zentz, Feminist Candidate Loses Debate Bid, UPI, Sept. 23, 1987, available in LEXIS, Nexis Library, UPI File (quoting John Armor, attorney for 1984 minorparty presidential candidate Sonia Johnson).

${ }^{103}$ See Thomas E. Patterson, Television and Presidential Politics: A Proposal to Restructure Television Communication, in ELEction CAMPAIGNS IN PresidenTIAL SELECTION 303 (A. Heard \& M. Nelson eds., 1987).

104 In contrast, Perot's multi-million dollar television advertising blitz and his repeated appearances on televised talk shows would have permitted his message to emerge, even had he been excluded from the debates. See, e.g., The Second Coming, NEwsweER, Nov./Dec. 1992 (Special Election Issue), at 86, 87 (noting that since Perot's medium was "all but exclusively paid television ... he had more to spend on media than Bush and Clinton combined."); Superhero, NEwSWEEK, Nov./Dec. 1992 (Special Election Issue), at 70, 72 (noting Perot's preference for "for talk radio and 
sant major-party endeavors to manipulate the presentation of issues and views to the public. If the significance of minor parties inheres in their ability to alter the political agenda and the distribution of major-party support, to assure major-party accountability while encouraging voter participation, and to perform key symbolic functions, ${ }^{105}$ they can best fulfill these roles with a presence in the presidential debate, the Super Bowl of politics.

Exclusion of third parties from debates frustrates this ideal in several ways. First, exclusion is tantamount to delegitimization. ${ }^{106}$ Debates "enhance support for the political system by legitimizing both nominees." 107 The negative implication of this proposition is that a candidate not on the debates cannot be legitimized. Absent legitimization-to say nothing of support-third parties will remain distant voices in the wilderness, unable to influence the political agenda, raise important yet overlooked issues, or hold the major parties accountable. ${ }^{108}$ Delegitimization, of course, is yet another blow to the weak electoral credibility currently enjoyed by thirdparty and independent candidates.

The absence of minor-party candidates from televised presidential debates also divests third-party supporters of the symbolic sense of participation in American politics. Debates have a communal importance, binding the electorate to the elected, imbuing viewers with a sense-even if not altogether warranted-of participation in a

TV, especially call-in shows"). Few third-party or independent candidates, however, have either the funds or the opportunities to present their views to the voting public. See supra notes 78-81. A debate appearance thus takes on increased importance.

${ }^{105}$ See supra Part I.

${ }^{106}$ Because third parties are seen as disrupters of the two-party system, their first task is establishing their legitimacy, something not required of the major parties. See ROSENSTONE ET AL., supra note 21, at 39. A minor party's inherently precarious position makes it particularly susceptible to delegitimization by a wide variety of means, including exclusion from debates. See supra notes 100-01 and accompanying text. Ross Perot exemplifies the legitimizing force of a good debate performance. See Fineman, supra note 73, at 47 (claiming that the debates "launched Perot"); Howard Fineman, Face to Face to Face, NEWSWEEK, Oct. 19, 1992, at 20 (noting that a Newsweek poll found that a plurality (43\%) of viewers thought Perot won the first debate); Firestone, supra note 31 at 29 (noting that Perot's impressive debate performance buoyed his campaign); Only One Answer Deep, N.Y. TIMES, Oct. 13, 1992 , at A22 (noting that Perot's strong performance on the debates "probably tempted many listeners to consider his candidacy afresh").

107 LANOUE \& SCHROTT, supra note 5, at 105 (emphasis omitted).

108 See ROSENSTONE ET AL., supra note 21, at 222 ("Minor parties are not so much safety valves for voters who want to blow off steam as they are checks on the major parties. They are a weapon citizens can use to force the major parties to be more accountable.") 
national process. ${ }^{109}$ If one's candidate is not seen discussing the important issues of the day in a preeminent national forum, the result is a sense of disenfranchisement that may find expression in political nihilism and ultimately lead to withdrawal from the political process. Inclusion of significant third-party candidates, on the other hand, signifies to their supporters that such candidates matter. Third-party debate participation is an important symbolic step toward the democratization of presidential politics. Inclusion of such candidates would give minor-party candidates "the opportunity to overcome the widespread attitude that third-party candidacies are a waste of time. ${ }^{n 110}$

\section{B. The Merits of Inclusion}

[Additional third-party candidates] should have been on stage with President Bush, Gov. Bill Clinton and Perot in their three debates. The quality of discussion could only have risen. [These alternate candidates] were labeled minor candidates, despite some of their ideas being innovative and many of the major candidates' ideas being bland. ${ }^{111}$

A third-party presence in debates would accelerate the cooptation effect, ${ }^{112}$ thereby increasing minor-party ability to influence the political agenda. A policy innovation espoused by a significant minor-party or independent candidate in a nationally televised debate is instantly broadcast to millions of American homes. Polls demonstrate the electorate's response to such proposals. If the response is sufficiently positive, political realities dictate that the two major candidates will jockey for primacy in assimilating the minor-party or independent candidate's ideas and support. If non-major-party nominees were included in debates, politically

${ }^{109}$ This political participation rationale for third-party candidate inclusion in debates derives from the notion "[t]hat politics can be an enriching experience separate from assessments of 'victory' or 'defeat." FRESIA, supra note 49, at 25-26; see also id. at 214 (" $[\mathrm{W}] \mathrm{e}$ are engaged in politics because to express an idea, or to reflect upon oneself, or to think honestly and publicly is in itself worthwhile and satisfying."); $c f$. MTTCHELL, supra note 5, at 5 ("[P]ast debates were informative and. . . stimulated voter interest."); Magarian, supra note 96 , at 877 (noting the argument that debates build confidence in American democracy). 70.

${ }^{110}$ Barmann, supra note 16, at 453; see also supra text accompanying notes 55 \&

111 Colman McCarthy, The Candidates Who Were Not Heard, WASH. POST, Nov. 3, 1992, at C10 ("The two major parties offer centrist and conventional strategies because, it is believed, most of the votes are in the middle. But how do we know if the outer edges are not given a place?").

112 See supra text accompanying notes 46-52. 
viable ideas that are important to Americans but have not found a voice in major-party platforms would more quickly wend their way into the political mainstream.

Second, a third-party candidate's presence would reduce the ability of the major parties to collude with each other in the manipulation of the debates. As currently structured, the televised presidential debates, especially the decision whether to debate and under what conditions, "epitomize the game of power and partisanship."113 This manipulation was brought into sharp relief in 1988, when the League of Women Voters responded to it by withdrawing as a debate sponsor. ${ }^{114}$

Major-party orchestration of when, how, and whether to debate continued in the 1992 presidential race, particularly on the part of

113 Debates and Public Service, CHRISTIAN ScI. MONITOR, July 9, 1987, at 15.

114 A sponsor of most of the televised presidential debates since 1976, the League of Women Voters withdrew its sponsorship of the second 1988 presidential debate, denouncing the rigidly choreographed debate format as both a "fraud" and "an attempt to hoodwink the American public." Stephen Knight, United States: Debate Sponsor Pulls Out Citing "Fraud, "Inter Press Serv., Oct. 5, 1988, available in LEXIS, Nexis Library, Wires File. League President Nancy Neuman charged that the candidates' organizations aim to add debates to their list of campaign-trail charades devoid of substance, spontaneity and honest answers to tough questions." Id. A 16page memorandum detailing the format of the debate, a joint effort of the Bush and Dukakis campaigns, drew particular fire from Neuman, who called it a "closed-door masterpiece," noting that the League was told to "take it or leave it." Id. Additionally, League Communications Director Stephanie Drea reported that the Bush campaign demanded a telephone connection to the debate's producer so that substantive changes could be made while the show was on the air, a gambit that had been used to shift the focus of the first Bush-Dukakis debate to foreign policy. Id.

The gap in sponsorship created by the resignation of the League was quickly filled by the Commission on Presidential Debates (CPD), a bipartisan group that had sponsored the first debate and was formed in 1987 by the Republican and Democratic national committees. See Mike Mills, Parties to Sponsor Debates in '88; Voters League Upset, L.A. TIMES, Feb. 19, 1987, at 13. The League of Women Voters has long believed that party-sponsored debates inevitably give short-shrift to minor-party candidates seeking inclusion. See id.; Knight, supra. The CPD acknowledged that it considered its "primary responsibility [to be] with the two major parties," although the Commission stated that it would not rule out including viable third-party candidates. See Mills, supra, at 16; cf. Who'll Protect the John Andersons?, N.Y. Times, Nov. 29, 1985, at A30 (expressing concern that the interests of independents and third-party candidates might not be protected in debates sponsored by the major parties).

No third-party candidates were included in the 1988 general election debates sponsored by the CPD or in the three primary season debates sponsored by the League. See Barmann, supra note 16, at 452. Though Ross Perot participated in the three 1992 presidential debates, the circumstances of his inclusion were redolent of a bilateral decision by the Bush and Clinton campaigns rather than an independent CPD determination. See infra note 225. 
the Bush campaign. ${ }^{115}$ Moreover, the decision to include Ross Perot appeared to be driven by a common Democratic and Republican view that an independent candidate's presence would help one side and hinder the other. ${ }^{116}$ As long as third-party participation is dictated by Democratic and Republican perceptions of political expediency, the two major parties will be able to continue their monopolistic hold on every aspect of the debates, a circumstance that will prevent the debates from ever fulfilling the potential they hold for informing the electorate.

Third, an independent or minor-party candidate's presence in debates stimulates voter interest. ${ }^{117}$ The 1992 debates, the first ever in which the two major-party candidates simultaneously debated a third-party candidate, drew the largest debate audiences in the history of the event. ${ }^{118} \mathrm{~A}$ fair inference is that increased interest in the debates was attributable, in large part, to the presence of Ross Perot, a significant independent candidate. ${ }^{119}$

Finally, a third-party candidate's presence in the debates would function as a wild card, lending the debates an element of unpredictability. Unpredictability, of course, necessitates increased preparation on the part of the candidates, and increased preparation spells "better" debates. Better because a minor-party or

115 Only after months of posturing followed by two days of heated meetings involving representatives of both campaigns did the two sides finally strike a deal about format. See Cohen, supra note 22 (stating that "Bush finally made a move after his obdurate opposition to the format, suggested by a bipartisan commission, caused cancellation of the first three scheduled meetings with Clinton"); see also Tom Baxter, Candidates Face Each Other Tonight: First Debate Called Crucial, ATLANTA CoNST., Oct. 11,1992 , at A1 (suggesting that the Bush campaign might have "outsmarted itself" by resisting earlier debate proposals and holding out until after Perot reentered the race);infra note 226.

${ }^{116}$ See Howard Fineman, Mixing It Up-Again, NEwSWEEK, Oct. 12, 1992, at 26, 27 ("With each side hoping that Perot would do more damage to the other, the two camps crossed their fingers and invited him to share the stage."). The Republicans viewed Perot's presence as a plus to President Bush, who they felt would look more "presidential" with two challengers simultaneously attacking him; the Clinton camp may have wanted Perot on the debates because his presence could have diffused a Bush attack. See Baxter, supra note 115, at Al (discussing the tactical advantages both sides hoped to gain through Perot's participation in the debates).

117 See Barmann, supra note 16, at 453.

118 See Kubasik, supra note 5, at 20 (reporting that the third debate was "the second-most-watched such TV event ever-behind [only the previous] debate."); Arthur Spiegelman, It Was Supposed to be an Election Nobody Cared About, Reuters, Oct. 22, 1992, available in LEXIS, Nexis Library, Wires File (noting that the debates "won the kind of ratings usually reserved for major sporting events").

${ }^{119}$ See, e.g., Spiegelman, supra note 118 (noting that experts credit Ross Perot with "helping to rewaken the sleeping giant of the American electorate"). 
independent candidate's participation would result in a fuller political dialogue. Better because the two major parties would be less able to restrict the subjects of discourse, and might in fact be forced to confront important public issues they otherwise would not. And better because, with candidates more prepared, with more issues discussed, and with the solicitation of a third point of view, the debates would simply be more informative. Since debates serve "the ideal of informing the public," 120 this result is in the best interests of all. In summary, exclusion from presidential debates is yet another restriction on third-party and independent candidates, a restriction to be decried because any such limitations on the "political effectiveness" of a group "threaten to reduce diversity and competition in the marketplace of ideas." 121

\section{The INADEQUACY OF THE JUdicial RESPONSE}

Having discussed the importance of a third-party or independent candidate's presence in the nationally televised debates, this Comment now examines several recent cases in which third-party candidates have sought inclusion in such arenas. This section will discuss the general lack of judicial solicitude to the plight of thirdparty candidates seeking inclusion on nationally televised presidential debates, and then conclude that judicial fiat is an impractical mechanism for insuring participation of third-party or independent candidates.

The federal judiciary has rejected a constitutional assault on exclusion of such a candidate from televised debates. In Johnson $v$. $F C C$, ${ }^{122}$ the D.C. Circuit unanimously affirmed the FCC's denial of a third-party candidate's complaint which sought to prohibit the broadcast of the 1984 presidential and vice-presidential debates unless she and her running-mate were included. ${ }^{123}$ The court rejected the plaintiffs' arguments that the debates "had become so institutionalized as to be a prerequisite for election" and that the plaintiffs' exclusion thus restricted their access to the ballot and impinged upon associational choices protected by the First

${ }^{120}$ Earl W. Foell, New, Improved Presidential Debates: Planning Now for '88, CHRISTIAN SCI. MONITOR, Apr. 2, 1985, at 3, 3.

${ }^{121}$ Anderson v. Celebrezze, 460 U.S. 780, 794 (1983) (finding that "the primary values protected by the First Amendment . . . are served when election campaigns are not monopolized by the existing political parties").

122829 F.2d 157 (D.C. Cir. 1987).

${ }^{123}$ See id. at 160. 
Amendment. ${ }^{124}$ It reasoned that "the broadcast access cases decided under the First Amendment [and on which plaintiffs relied] do not support [their] claims to be included in the televised debates." 125

While recognizing the plaintiffs' fear "that the voices of minorparty candidates may be drowned out by the superior financial resources of the major parties, or encounter discrimination from conscious or unconscious biases of large broadcasters," 126 the court nonetheless concluded that this concern was met by "the several access provisions of the Communications Act [that] ensure that political debate will not be monopolized by one of a very few candidates. ${ }^{\text {127 }}$ In addition, the court explained, the petitioners sought not general access, but the specific right to appear on a specific program sponsored by a specific organization. ${ }^{128}$ Granting such a right, the court concluded, would contravene the "First Amendment balance struck in the statutory scheme ${ }^{129}$ and would raise the specter of increasing "Government control over the content of broadcast discussion of public issues." $" 130$

The political naiveté the Johnson court demonstrated by failing to appreciate the enormous impact of the debates is trouble-

$124 \mathrm{Id}$. at 159 .

125 Id. at 164. As for the plaintiffs' claim that the Communications Act and judicial precedent mandated inclusion, the court held: "[T]he Commission properly determined that petitioners had no right recognized by the Communications Act or the broadcast-access precedents to be included in the televised debates." Id. at 158. The Johnson court relied, in part, on Columbia Broadcasting Sys. v. Democratic Nat'l Comm., 412 U.S. 94 (1973) (upholding a ban on editorial advertising imposed by broadcast licensees, while rejecting Fairness Doctrine and First Amendment challenges, since access claims must be examined in light of the regulatory scheme that has evolved from the Communications Act). Congress has chosen to protect the public's First Amendment rights to broadcasting, the D.C. Circuit noted, "'by relying on broadcasters as public trustees, periodically accountable for their stewardship, to use their discretion in ensuring the public's access to conflicting ideas.' Johnson, 829 F.2d at 162 (quoting Respondent's Brief, Kennedy for President Comm. v. FCC, 636 F.2d 417, 432 (1980) (No. 80-1482)).

126 Johnson, 829 F.2d at 161 .

${ }^{127}$ Id. The D.C. Circuit also relied on, but did not critically reexamine, its earlier decision in Chisholm v. FCC, 538 F.2d 349 (D.C. Cir. 1976) (finding debates between qualified political candidates initiated by nonbroadcast entities to be "bona fide news events" and thus exempt from the equal opportunity requirements of $\$ 315(a)$ of the Communications Act), cert. denied, 429 U.S. 890 (1976). The decision made possible all subsequent debates. See JAMIESON \& BIRDSELL, supra note 8, at app. 2.

${ }^{128}$ See Johnson, 829 F.2d at 162.

$129 \mathrm{Id}$.

${ }^{130}$ Id. (quoting Columbia Broadcasting Sys. v. Democratic Nat'l Comm., 412 U.S. 94, 126 (1973)). 
some. ${ }^{131}$ The court did recognize that inclusion of the appellants in the debates "undoubtedly would have benefitted their campaign." 132 At the same time, however, the D.C. Circuit refused to equate exclusion from the debates with exclusion from the ballot, explaining: "[ $t]$ he former removes only one of the great number of avenues for candidates to gain publicity and credibility with the citizenry, while the latter drastically restricts voters' ability to choose the omitted candidate." 133 Yet the televised presidential debate is an event of such political magnitude that it is not merely "one of a great number of avenues" for the attainment of credibility and publicity; it is the avenue. ${ }^{134}$ By claiming that exclusion from the debates did not prevent the petitioner from "waging an effective campaign," 135 the court additionally demonstrated a judicial myopia common to opinions in this area: the belief that exclusion from nationally televised presidential debates does not pose a substantial obstacle to a significant non-major party candidate.

Displaying limited recognition of the debates' import, the court also explained that the Constitution is not an instrument for insuring that all candidates are equal in terms of financial strength and publicity, and does not mean to aid in "overcoming disadvantages in money and image frequently encountered by minor-party candidates." 136 Given the Johnson decision, as well as the mixed results of other challenges by third-party plaintiffs to various exclusionary electoral procedures, ${ }^{137}$ a bare constitutional claim for inclusion of third-party or independent candidates in televised presidential debates would seem to harbor dismal prospects of success. For one third-party candidate, however, the statutory arena seemed to offer a more promising avenue of judicial attack.

131 The "significance" of Johnson's candidacy was questionable, however. Although Johnson and her Citizens Party running mate appeared on 19 state ballots and came in fifth place in the 1984 national presidential race, the two garnered only $.08 \%$ of the vote. See Johnson, 829 F.2d at 158-59; see also Zentz, supra note 102.

132 Johnson, 829 F.2d at 165.

${ }^{133} I d$. at 164-65. But see infra text accompanying note 146.

${ }^{134}$ See supra note 99.

${ }^{135}$ Johnson, 829 F.2d at 165.

${ }_{136} \mathrm{Id}$.

137 Compare, e.g., Anderson v. Celebrezze, 460 U.S. 780 (1983) (finding a state's early filing deadline for minor-party candidates constitutionally infirm) with Chandler v. Georgia Pub. Telecommunications Comm'n, 917 F.2d 486 (11th Cir. 1990) (holding that a public television station's decision not to include third-party candidates in televised debates does not violate the Constitution). For ballot-access cases in which the Supreme Court has found a state law unconstitutional, see supra note 83. 
In Fulani v. League of Women Voters Educ. Fund, ${ }^{138}$ presidential candidate Lenora Fulani brought a statutorily based third-party challenge to her exclusion from the presidential debates before the Second Circuit. Using the theory of competitive advocate standing to allege redressable harm, ${ }^{139}$ Fulani contended that the League of Women Voters, the sponsor of the primary debates, had engaged in "partisan" activity when it refused to allow her to participate in the 1988 Democratic and Republican primary debates. ${ }^{140}$ Accordingly, she claimed, the League's tax-exempt status under $\$ 501(c)(3)$ of the Internal Revenue Code, granted to organizations operated in a nonpartisan manner and exclusively for charitable or educational purposes, should be revoked. ${ }^{141}$ Without such tax-exempt status, a Federal Election Commission regulation would have prevented the League from sponsoring the debate. ${ }^{142}$

Although the Second Circuit held that Fulani satisfied the applicable standing requirements to litigate the League's tax-exempt status, ${ }^{143}$ the court concluded that Fulani's claim failed on the merits, since the League's exclusion of Fulani from the primary

${ }^{138}$ Fulani I, 882 F.2d 621 (2d Cir. 1989).

${ }^{139}$ See id. at 625 . Under the competitive advocate standing theory, also known as the competitive political advocate theory and the competitive political advantage theory, a complainant can "satisfy the Constitution's case or controversy requirement by alleging that discriminatory enforcement of a statute grants an unfair advantage to a political competitor which thereby diminishes the plaintiffs' ability to compete effectively in the political arena." Jordana G. Schwartz, Note, Standing to Challenge Tax-Exempt Status: The Second Circuit's Competitive Political Advocate Theory, 58 FORDHAM L. REV. 723, 723 (1990). See generally Magarian, supra note 96 at 855-67 (comparing the Second Circuit's approach to the competitive advocate standing theory to that of the D.C. Circuit).

${ }^{146}$ See Fulani I, 882 F.2d at 623 .

141 See id.

${ }^{142}$ See $i d$. at $627-28$ (citing 11 C.F.R. $\$ 110.13(\mathrm{a})(1)$ (1988) which provides in pertinent part that a "non-profit organization . . . exempt from federal taxation under 26 U.S.C. 501(c)(3) . . . and which does not endorse, support or oppose political candidates or political parties may stage nonpartisan candidate debates").

${ }^{143} \mathrm{See}$ id. at 628. To have standing to sue, one must prove: (1) a "personal injury" that is (2) "fairly traceable to the defendant's allegedly unlawful conduct" and (3) that requested relief is likely to redress. Id. at 624 (quoting Allen v. Wright, 468 U.S. 737, 751 (1984)). "But for the government's refusal to revoke the League's taxexempt status," the court held, "the League, as a practical matter, would have been unable to sponsor the allegedly partisan debates which caused the injury of which Fulani complains." Id. at 628. Several commentators have agreed that in granting Fulani standing, the Fulani $I$ court properly applied the standing doctrine. See Magarian, supra note 96, at 855 ("[A] candidate should have standing to challenge debate sponsors' tax status . . . ."); Schwartz, supra note 139, at 737 ("[C]ompetitive advocate standing was properly applied by the court in [Fulani $]^{\prime \prime}$ ). 
debates, "intra-party competitions," did not constitute impermissible "partisan" activity. ${ }^{144}$ Fulani, the court noted, "was neither a candidate nor a participant" in either of the primaries that were the subject of the League's voter education program, and so she was properly excluded. ${ }^{145}$

The Second Circuit's opinion on the merits has been convincingly criticized by at least one commentator, who urges that the court botched the doctrinal analysis by

fail[ing] to recognize that at all stages of a campaign, the major parties compete against each other, and third-party candidates compete against the major-party candidates. The court's conception of the primary season as "intra-party" competitions fails to recognize that the ballot qualification process pits all parties against each other even during the primary season. ${ }^{146}$

The court's narrow view of the impact of debates, in fact, was reminiscent of the D.C. Circuit's characterization of these events in Johnson v. FCC. ${ }^{147}$

Despite this cramped view of "competition," the court's opinion at least left open the possibility, indeed suggested, that in a general election debate, a different standard of participation might obtain. The court stressed that "[i]t is of critical importance that the ... debates were not general election debates. Rather, they were primary season debates ...."148 The dictum continues in this remarkable vein, an unambiguous judicial recognition of the significance of debates, and a corresponding judicial sensitivity to the competitive disadvantage wrought by exclusion:

In this era of modern telecommunications, who could doubt the powerful beneficial effect that mass media exposure can have today on the candidacy of a significant aspirant seeking national political office. The debates sponsored by the League were broadcast on national television, watched by millions of Americans, and widely covered by the media. It is beyond dispute that participation in these debates bestowed on the candidates who

${ }^{144}$ See Fulani $I, 882$ F.2d at $628-30$.

145 Id. at 630.

146 Barmann, supra note 16 , at 462 (citation omitted).

147 See supra text accompanying notes 131-35.

148 Fulani I, 882 F.2d at 629; see also Sturgess, supra note 23, at 2 ("The ruling leaves open the possibility that in a general election, a different standard of participation would apply."). 
appeared in them some competitive advantage over their nonparticipating peers. ${ }^{149}$

The competitive disadvantage confronting Fulani, the court noted, "palpably impaired her ability to compete on an equal footing with other significant presidential candidates," and thus constituted sufficient "injury" for standing purposes. ${ }^{150}$ This solicitous rhetoric, however, proved to be cold comfort, for it did not affect the court's conclusion that the League's behavior was not "parti$\operatorname{san}^{n}{ }^{151}$

Although the competitive advocate standing theory seemed to hold promise for a third-party candidate seeking a slot on a nationally televised presidential debate, the doctrine proved unavailing when Fulani relied on it to sue the 1992 presidential debate sponsor, the Commission on Presidential Debates, in the D.C. Circuit. ${ }^{152}$ The procedural posture of Fulani II was identical to that of Fulani I, except that Fulani sought inclusion in the nationally televised presidential debates rather than in the primary debates. However, the D.C. Gircuit held that Fulani lacked standing to challenge the tax-exempt status of the CPD. ${ }^{153}$ In disagreeing with the Second Circuit's competitive advocate standing analysis, the D.C. Circuit found the CPD's tax-exempt status to be an indirect cause of Fulani's alleged injury; the court viewed both the FEC regulation and the CPD's sponsorship of the debates as among the intervening causal agents that rendered the injury not fairly traceable to the CPD's tax-exempt status. ${ }^{154}$ The court's opinion was strikingly formalistic, bereft of the Second Circuit's explicit understanding of both the importance of the televised debates and the grave impact of exclusion from such fora on third-party candidates. Additionally, the majority's standing analysis was

149 Fulani I, 882 F.2d at 626.

${ }^{150}$ Id. The majority described the injury as the "partisan restriction of [Fulani's] opportunities to communicate her political ideas to the voting public at large." Id. at 627 .

151 Id. at 630.

152 See Fulani II, 935 F.2d 1324 (D.C. Cir. 1991), cert. denied, 112 S. Ct. 912 (1992).

153 See id. at 1325.

154 See id. at 1329 ("[W]hile the IRS's decision to provide the CPD with tax-exempt status is a cause of Fulani's claimed injury, it is merely one in a chain of independent causal factors necessary to achieve this injury."). 
persuasively criticized by Judge Mikva in dissent ${ }^{155}$ and by several commentators. ${ }^{156}$

Fulani II seemed to spell doom for the future of suits by thirdparty or independent candidates seeking inclusion in televised debates. Such plaintiffs, after all, had now been convincingly defeated in federal courts of appeal on both constitutional and statutory grounds. In October of 1992, however, Fulani dutifully followed the Second Circuit's Fulani $I$ cue, ${ }^{157}$ bringing suit in the Southern District of New York against the Secretary of the Treasury and the Commissioner of the Internal Revenue Service for their "alleged failure to enforce the non-electioneering prohibitions" of $\S 501(\mathrm{c})(3)$ of the Internal Revenue Code by not mandating her inclusion in the televised general election presidential debates. ${ }^{158}$

155 See id. at 1331 (Mikva, J., dissenting). First, Mikva asserted that the majority paid "only lip service" to the injury alleged by the appellants, the gist of which was that Fulani's credibility as a "spoiler" and public advocate was undermined by her absence from the debates, and that allowing two major-party candidates to debate only each other unfairly boosted their campaigns relative to hers. Id. at 1331-32 (Mikva, J., dissenting). In agreeing with the competitive advocate standing theory espoused by the Second Circuit in Fulani I, Mikva criticized the majority for "[failing] to come to terms with Fulani's injury." Id. at 1333 (Mikva, J., dissenting).

Second, Mikva argued, the majority botched its traceability analysis by ignoring precedent, which mandated that the "presence of intervening actors in a chain of events that leads from the alleged legal violation to the alleged harm will not necessarily defeat standing." Id. at 1333 (Mikva, J., dissenting). Third, Mikva noted that the majority had misapplied redressability requirements in holding that there was not a "substantial likelihood" that Fulani's injury would be redressed by a favorable decision on the merits, since the CPD, faced with the choice of opening its debates to more candidates or losing its tax exemption, might simply decide not to sponsor presidential debates at all. Id. at 1335 (Mikva, J., dissenting). Fulani's claim, Mikva concluded, raised the possibility that Congress had "tilt[ed] the electoral playing field .... I therefore dissent from a decision that insulates from review federal complicity in keeping minor political parties off the national stage." Id. at 1337 (Mikva, J., dissenting).

${ }^{156}$ See Magarian, supra note 96, at 884-85 (arguing that the Second Circuit's "recognition of the breadth and depth of the injuries which exclusion from televised debates caused Fulani create[s] a compelling foundation for standing" that has support in current Supreme Court standing doctrine); Schwartz, supra note 139, at 736 (arguing that the competitive advocate standing theory "has strong antecedents in cases holding that economic and political competitors may allege injury sufficient to confer standing"). Additionally, "political scientists' findings about minority-party candidates' roles in the American electoral system bolster . . . justifications . . . to find standing . ..." Magarian, supra note 96 , at 867 . In fact, it is no overstatement to claim that "[a]s the government becomes increasingly involved in regulating the political process, the likelihood that some political participants will glean advantages at the expense of others is increased." Schwartz, supra note 139, at $736 \mathrm{n} .106$.

${ }^{157}$ See supra note 148 and accompanying text.

${ }^{158}$ Fulani III, No. 92 Civ. 7182 (SWK), slip op. at 1 (S.D.N.Y. Oct. 9, 1992). 
Fulani sought a temporary restraining order and a preliminary injunction revoking or suspending the CPD's tax-exempt status unless the organization (a) included her in the debates or (b) withdrew its sponsorship of the debates. ${ }^{159}$ The court denied Fulani's request for preliminary injunctive relief, holding that she failed to make the strong showing required for such relief. ${ }^{160}$

The district court did note, however, that Fulani "[had raised] important issues which will be determined in the course of this litigation. ${ }^{\text {161 }}$ Fulani's latest judicial salvo, however, may be a misfire: as the district court suggested in dictum, it may never have to reach the merits of her suit because her claims may be barred by the doctrine of collateral estoppel as a result of the D.C. Circuit's earlier opinion in Fulani $I$, and the suit may be dismissed due to Fulani's failure to join an indispensable party, the CPD. ${ }^{162}$

In summary, the recent judicial response to third-party candidates' petitions for inclusion on televised debates has been tepid at best. The D.C. Circuit has both dismissed a constitutionally based appeal and rejected the competitive advocate standing theory as a basis for minor-party candidates to seek inclusion in the debates or revocation of the debate sponsor's tax-exempt status. Although the Second Circuit seems sympathetic to the competitive advocate standing theory, the procedural posture of the current suit against the heads of the Treasury and the IRS renders it unlikely that the Second Circuit will ever reach the merits. ${ }^{163}$ Finally, the Supreme Court, by denying certiorari in Fulani II, has indicated present unwillingness to resolve the circuit split about the competitive advocate standing theory. ${ }^{164}$ A survey of the judicial landscape, then, indicates that the courts are not soon likely to grant thirdparty candidates relief.

Even if the judicial treatment of minor-party candidates seeking inclusion in nationally televised presidential debates were more solicitous than it has been-and despite the strong competitive

159 See id. at 2. In the alternative, Fulani demanded that the CPD adhere to its published selection criteria by revoking its invitation to Perot to participate in the debates. See id.

160 See id. at 3.

161 Id.

162 See id. at 4-5.

163 Even if the Second Circuit did find that Fulani's latest case should be heard on the merits, its earlier dictum would not be binding, so one can only speculate on how the court would pass on a claim by a third-party or independent candidate who sought to participate in the presidential, rather than the primary, debates.

${ }_{164}$ See Fulani II, 935 F.2d 1324 (D.C. Cir. 1991), cert. denied, 112 S. Ct. 912 (1992). 
advocate standing claim that a significant third-party or independent candidate could make-the judiciary is not the appropriate body to grant relief to such candidates. ${ }^{165}$ Judicially mandated inclusion would likely be a simplistic, narrow, fact-specific determination that would not concern itself with the necessarily complex, fine-tuned political judgments that need to be made. Such inclusion would likely encourage a spate of lawsuits by third-party or independent candidates of varying national stature, each claiming to be similarly situated to a candidate who has already been granted judicial relief.

Which third-party or independent candidates should be included in the debates? Certainly, practical considerations dictate that allowing dozens of fringe candidates to participate in a nationally televised debate with the two major candidates is neither wise nor predictable. ${ }^{166}$ What realistic criteria can be formulated to determine which third-party or independent candidates to include and which to exclude? How can one be certain that the major parties will agree to participate in such debates? The task of answering these and similar questions, of ironing out solutions to political problems, is a job for which the legislature is uniquely qualified. Only Congress has the time, the resources, and the knowledge to restructure, in programmatic fashion, nationally televised debates.

This Comment will now examine and evaluate three current legislative proposals that would reform the debate process by institutionalizing the debates. After analyzing all three proposals, this Comment will urge the adoption of the third, the best hope for assuring that the electorate can enjoy the merits of legislative inclusion.

${ }^{165}$ But see Magarian, supra note 96 , at 885 (contending that "[u]njust and unnecessary political discrimination against minor-party candidates creates a breach into which the independent judiciary is ideally suited to step").

166 Twenty-three candidates were listed by the FEC in its compilation of presidential candidates on the 1992 general election ballots of each state and the District of Columbia. See FEC NEWS RELEASE, supra note 84, at 1-3. In the 1988 election, there were 168 declared candidates for the office of the presidency, though not all were on the ballot. See Dunn, supra note 68, at 649. 


\section{The Legislative Response}

\section{A. The Constitutionality of Institutionalizing Debates}

Institutionalizing presidential debates by conditioning eligibility for federal campaign fund payments on candidate participation in debates has been a controversial notion. ${ }^{167}$ Some commentators have questioned the constitutionality of institutionalized debates, ${ }^{168}$ others the wisdom of them. ${ }^{169}$ Yet institutionalization has drawn strong support. ${ }^{170}$ Supporters of institutionalization

167 The debates themselves, regular features of the last five elections, seem to have become firmly entrenched. See John Omicinski, Presidential Debates Made for Good Television, Gannett News Serv., Oct. 20, 1992, available in LEXIS, Nexis Library, Wires File (assessing impact of the high ratings of the 1992 debates on the future of presidential debates). Yet the major parties' inveterate haggling over debates and gamesmanship about whether to participate, see supra notes 113-16 and accompanying text, indicate that the debates have not yet become a sine qua non of presidential races.

${ }^{168}$ See, e.g., MrTCHELL, supra note 5, at 80 (suggesting that outright requirements and funding coercion probably will not pass constitutional muster); How to Ensure Presidential Debates, supra note 8, at 15 (same).

${ }^{169}$ See, e.g., LANOUE \& SCHROTT, supra note 5, at 155-56 (noting one commentator's argument that linking federal matching funds to debate participation would intrude on "the candidates' freedom to seek votes in whatever legal manner they deem most beneficial" and "would have negative implications for democratic theory far beyond whatever benefits are derived from the debates themselves"); MTTCHELL, supra note 5, at 5 (concluding that while presidential debates should become a regular feature of the campaign, they should not be mandated by law or regulation); How to Ensure Presidential Debates, supra note 8, at 15 (arguing that, despite the value of presidential debates, "it seems unwise for the government to intrude on this aspect of campaign decision-making").

170 For example, Sen. Graham has said:

[U]ncertainty ... about whether debates will occur can destroy their effectiveness and purpose. ... If both voter and candidate knew the debates were going to happen, then more time could be spent on preparation than on campaign staffs negotiating their candidates out of having the debate. Voters could count on a forum to provide them with knowledge with which they could comfortably go to the polls.

137 CoNG. REC. S6102 (daily ed. May 17, 1991).

Without institutionalization, candidates can insist on their terms, and if these terms are not met, they can walk away without fear of retribution. See Germond \& Witcover, supra note 11, at 1244. Columnist David Broder has argued that the debates belong to the public and not the candidates: "We have accepted . . . far too passively the notion that it is up to the candidates and their advisers to determine what takes place and what's talked about, and how it's talked about in a presidential campaign.'" 137 CoNG. REC. E643 (daily ed. Feb. 26, 1991) (remarks of Rep. Markey) (quoting Broder, and further stating that the public "deserves and should demand substantive debates in return for its investment"); 137 CONG. REC. E397 (daily ed. Feb. 4, 1991) (statement of Rep. Penny) (arguing that institutionalization will "help 
recognize that making reception of public funds contingent on participation is an effective way to insure that debates occur. ${ }^{171}$ It is also an acknowledgement that candidates have an obligation to inform and educate the populace whose tax dollars subsidize their campaigns. ${ }^{172}$ Conditioning funds on participation may, in fact, be the only method for insuring that "significant" minor-party or independent candidates are included in debates with nominees of the two major parties, rather than being left to debate amongst themselves or to rely on some other form of television exposure. ${ }^{173}$ Ironically, Ross Perot's presence on the 1992 presidential debates, rather than assuring future minor-party candidates of slots on these fora, may have decreased the likelihood of future thirdparty participation. As one commentator notes, "Perot's performance as both wild-card and trump-card is likely to give future incumbents pause about permitting third-party candidates aboard." 174 Institutionalization is thus a proposal of pressing moment.

As a threshold matter, one should understand that proposals for debate institutionalization do not entail compulsory debate participation by major-party candidates. Compelling a candidate to

to rekindle dwindling voter participation and interest in our elections"); How to Ensure Presidential Debates, supra note 8 , at 15 (reasoning that institutionalizing debates would prevent "speculation over them from overshadowing other elements of the campaign, including the debates themselves").

171 Institutionalization also insures that candidates cannot extract concessions as to debate format and substance by threatening to refuse to participate. See Susan E. Spotts, Recent Developments, The Presidential Debates Act of 1992, 29 HARV. J. ON LEGIS. 561, 561 (1992) (observing that in 1988, "[s] ince the candidates had the power to decide whether or not they would debate, they were able to dictate the terms of the debate"). Absent institutionalization, "presidential debates are scheduled only when campaign managers find them beneficial to their candidates' campaign strategies, rather than when they would be most helpful for the voters." Id.

172 See id. at 562.

173 See id. at 575-79; see also MITCHELL, supra note 5, at 87 (arguing that majorparty candidates are not likely to agree voluntarily to debate minor-party or independent candidates). Organizing separate debates for minor-party candidates and major-party candidates has been attempted. Such a proposal, however, is selfdefeating because the very point of opening the debates is to include minor-party and independent candidates in a forum with the major-party candidates, and thus assure such candidates of an ample audience and the ensuing benefits that can only obtain with a major-party presence. As a case in point, a 1992 presidential debate organized for alternative candidates was attended by merely 180 people, while the second BushClinton-Perot televised debate attracted about 80 million viewers. See G.L. Marshall, Alternative Candidates Offer Sharp Contrast, UPI, Oct. 16, 1992, available in LEXIS, Nexis Library, UPI File.

174 Omicinski, supra note 167. 
speak both at a certain time and in a particular forum would be violative of the First Amendment. ${ }^{175}$ Rather, the proposals simply threaten to withhold certain federal funds from major-party candidates who skirt debates with "significant" and national thirdparty or independent nominees. The assumption is that this threat will function as a sufficient incentive to insure appearance of the Democratic and Republican candidates. Given the vast amount of money received by major-party candidates through public funding, this assumption would seem a sound one. ${ }^{176}$ Yet one must still inquire as to whether tying receipt of federal funds to participation in certain debates is an unconstitutional restraint on speech.

The constitutionality of such legislation is supported by several cases in which the Court has upheld the government's right to choose what types of activities it wishes to subsidize. ${ }^{177}$ Those who object to making receipt of federal campaign funds contingent on participation in presidential debates contend that such a statute is an impermissible congressional burden on freedom of speech, and thus violative of the First Amendment. ${ }^{178}$ Since there is no

175 The First Amendment also comprehends the right not to speak. See, e.g., Wooley v. Maynard, 430 U.S. 705, 714 (1977) (stating that First Amendment protection includes "both the right to speak freely and the right to refrain from speaking at all").

176 During the 1992 primary elections alone, Clinton received $\$ 12.5$ million in matching funds, and Bush \$10.1 million. See FEC NEWS RELEASE, supra note 84, at 1. Of the $\$ 173.7$ million the 1992 election cost the American taxpayers, $\$ 155.2$ million went to the two major candidates, with Clinton and his campaign receiving $\$ 78.8$ million, and Bush and his campaign \$76.4 million. See Campaign Cost, supra note 78.

177 This point is perhaps best illustrated by the line of abortion funding and socalled "gag-order" cases. See, e.g., Rust v. Sullivan, 111 S. Ct. 1759, 1772 (1991) (holding that federal regulations did not violate the Constitution where they prohibited projects that receive Title $X$ funds from counseling, referring, or providing information regarding abortion as a method of family planning); Webster v. Reproductive Health Servs., 492 U.S. 490, 507-11 (1989) (holding that the government has no constitutional duty to subsidize an activity merely because it is constitutionally protected and may choose to allocate public funds for medical services relating to childbirth and not for abortions); Regan v. Taxation with Representation, 461 U.S. 540 (1983) (upholding as constitutional the denial of tax benefits to nonprofit organizations exercising their First Amendment right to lobby); Harris v. McRae, 448 U.S. 297, 312-18 (1980) (holding that the federal government or states may refuse to fund medically necessary abortions because the existence of a constitutionally protected right does not obligate the government to grant the funds necessary to exercise that right).

${ }^{178}$ Put another way, institutionalization implicates the doctrine of "unconstitutional conditions," which states that "the government may not grant a benefit on the condition that the beneficiary surrender a constitutional right, even if the government may withhold that benefit altogether." Kathleen M. Sullivan, Unconstitutional 
constitutional entitlement to campaign funds, however, the government may make one course of action more attractive than another by choosing to fund only the activity it wishes to encourage. ${ }^{179}$ Here, the government wants to encourage participation in debates. Making one choice (participation in certain debates) preferable to another (non-participation) by funding only candidates choosing the former clearly is not analogous to a naked penalty of or an impermissible burden on those who exercise their First Amendment right not to participate in debates. In short, insofar as institutionalization comprehends a decision to fund a particular activity, legislative use of a carrot rather than a stick is permissible under the Supreme Court's most recent decisions.

Two Supreme Court opinions, however, reject government attempts to tailor provision of benefits to the relinquishment of First Amendment rights, thereby offering contradictory analysis. ${ }^{180}$ Accordingly, institutionalization would represent an impermissible condition on speech rather than a permissible funding regulation. Yet one commentator suggests that even if the Court were inclined to follow the contradictory analysis espoused by these cases in future suits, two matching-fund cases still urge the constitutionality of a bill tying reception of federal campaign funds to debate participation. ${ }^{181}$ Finding such a bill unconstitutional

Conditions, 102 HARV. L. REv. 1415, 1415 (1989). Here, the constitutional right is freedom of speech, the benefit, campaign funds.

179 See supra note 177.

${ }^{180}$ See FCC v. League of Women Voters, 468 U.S. 364 (1984) (finding unconstitutional an act that denied eligibility for federal funding to those broadcasters who choose to editorialize); Perry v. Sinderman, 408 U.S. 593 (1972) (finding unconstitutional a state college's attempt to condition a professor's continued employment on the professor's promise to refrain from exercising his constitutional right to criticize the school administration).

${ }^{181}$ See Spotts, supra note 171, at 570-79 (citing Buckley v. Valeo, 424 U.S. 1 (1976) (conditioning receipt of federal matching funds on a candidate's agreement to accept certain expenditure limitations is permissible, since a "significant interference" with the candidate's constitutional rights may be overridden by a "sufficiently important" governmental interest), and Republican Nat'l Comm. v. FEC, 487 F. Supp. 280 (S.D.N.Y.), aff d, 445 U.S. 955 (1980) (conditioning eligibility for matching funds on a candidate's agreement to accept expenditure limitations did not violate First Amendment)). Analyzing legislative initiatives to institutionalize debates, Spotts concludes that the government has a sufficiently important interest in requiring major-party participation in debates in order to assure that the American voter is wellinformed; that debates offer the best hope for providing voters with a serious discussion of the issues, and so institutionalization proposals satisfy the constitutional requirement of narrow-tailoring; and that the candidates' First Amendment rights are not unduly infringed by such legislation. See Spotts, supra note 171 , at 570-75. In addition, Spotts offers the argument that adoption of a bill providing for a non-major- 
would likely threaten Rust and necessitate heroic judicial efforts at distinguishing the abortion-funding, gag-order, and matching-fund cases from a legislative proposal to use federal funding to encourage debate participation. ${ }^{182}$ Given that the weight of Supreme Court precedent is aligned with the constitutionality of institutionalization, such a bill would likely pass constitutional muster. ${ }^{183}$

\section{B. Three Proposals}

In discussing three recent proposals for institutionalizing debates, we must examine them in the context of their potential for insuring the inclusion of significant third-party or independent candidates. ${ }^{184}$ Representative Charles Bennett's Presidential Candidate Debate Act of 1991 would amend the Internal Revenue Code to require "certain [presidential] candidates" to participate in debates in order to receive payments under the Presidential Election Campaign Fund Act. ${ }^{185}$ This bill also would amend $\S 9002$ of the Internal Revenue Code by defining "presidential candidate debate" as "a debate at which each candidate nominated for election to the office of President of the United States by a major party appears

party presence on nationally televised debates would actually strengthen the governmental interest, inasmuch as "inclusion of third-party candidates could significantly improve the educational value of the debates." Id. at 579.

182 Additionally, there are countervailing constitutional interests that factor into the calculus, militating against a finding of unconstitutionality. Chief among them are (1) the rights of the auditors, see Board of Education v. Pico, 457 U.S. 853 (1982); (2) the rights of minor-party candidates, see Magarian, supra note 96, at 857 (arguing that even though both the Second and D.C. Circuits denied Lenora Fulani's appeals for inclusion in televised debates, "the fact that neither [court] challenged Fulani's constitutional bases confirms the constitutional tenor of [her] alleged injuries"); and (3) the rights of voters, see 138 S. 2213, 102d Cong., 2d Sess. $\$ 2$ (1992) (stating that "the right of eligible citizens to participate in the election process as informed voters, provided in and derived from the first and fourteenth amendments to the Constitution, has consistently been protected and promoted by the Federal Government").

${ }^{183}$ This conclusion is shared by Spotts, supra note 171, at 568-79; see also Michael Rovaka \& Arthur Block, Rainbow Lobby, Inc., Statement in Support of The Democracy in Presidential Debates Act (H.R. 791) and the Presidential Debates Act of 1992 (S. 2213): The First Amendment Issues, at 26 (May 1, 1992) (on file with author) (concluding that Penny's bill is constitutional, even if it minimally infringes First Amendment rights).

${ }^{184}$ Some of the substantive provisions of these bills, such as those concerning the number and length of the debates, and the topics to be covered, are beyond the scope of the present inquiry.

185 See H.R. 60, 102d Cong., 1st Sess. (1991) (statement of purpose). As of January 3, 1991, the bill had attracted no co-sponsors. H.R. 60: Presidential Candidate Debate Act of 1991, Bill Tracking Rep., Jan. 3, 1991, available in LEXIS, Legis Library, Bltrck File. 
and participates." 186 This restrictive definition of "debate," however, would neither foster the likelihood of a third-party candidate being invited to participate, nor exact a penalty from the major-party candidates for refusing to debate a "significant" thirdparty or independent candidate. This bill clearly contemplates compulsory debates between the two major-party candidates only.

In contrast, the National Presidential Debates Act, co-sponsored by Senator Bob Graham and Representative Edward Markey, has as its goal amending the Internal Revenue Code to require "any general election candidate" receiving money from the Presidential Election Campaign Fund to participate in debates "with other such candidates." 187 Significantly, this provision would seem to assure a third-party or independent candidate who received federal matching funds a spot on the televised presidential debates. ${ }^{188}$ The bill is flawed, however, because it further provides that the debate sponsor be "a nonpartisan or bipartisan organization". 189 This provision is intended to preserve the role of the 1988 and 1992 debate sponsor, the CPD. 190

CPD sponsorship of the debates has generated a spate of critical commentary, much of it denouncing a perceived attempt by the major parties to perpetuate their monopolistic control of the electoral system and the electorate. ${ }^{191}$ The tenor of some of the

${ }^{186}$ H.R. 60, 102d Cong., 1st Sess. $\$ 2$ (1991).

${ }^{187}$ S. 491, 102d Cong., Ist Sess. (1991) (statement of purpose); H.R. 1112, 102d Cong., 1st Sess. (1991) (statement of purpose). The House and Senate versions of the bill are identical. For convenience's sake, the Comment shall hereinafter refer exclusively to the Senate version. As of June 6, 1991, the House bill had 26 cosponsors, 24 of whom were Democrats. See H.R. 1112: National Presidential Debates Act of 1991, Bill Tracking Rep., June 6, 1991, available in LEXIS, Legis Library, Bltrck File. As of February 26, 1991, the Senate bill had not attracted any co-sponsors. See S. 491: National Presidential Debates Act of 1991, Bill Tracking Rep., Feb. 26, 1991, available in LEXIS, Legis Library, Bltrck File.

188 For an explanation of how one qualifies for federal matching funds, see supra note 79.

${ }^{189}$ S. 491, 102d Cong., 1st Sess. § 2(a) (1991) (this provision would amend chapter 95 of the Internal Revenue Code of 1986 to provide for debate sponsorship).

190 The word "bipartisan" was added "to include the possibility of sponsorship by the [CPD], which skillfully staged the 1988 general election debates and which has continued to play an active and positive role in calling for institutionalized debates." 137 CoNG. REC. E643 (daily ed. Feb. 26, 1991) (remarks of Rep. Markey). For a discussion of the CPD's role in the 1988 debates, see supra note 114.

${ }^{191}$ See MrTCHELL, supra note 5, at 58 (arguing that the debates should be sponsored by a nonpartisan organization because ceding control to the major parties insures that format and issue determination will be motivated by what is best for the major-party candidates rather than by what is most conducive to informing the public); Debates and Public Service, supra note 113, at 15 (" $[T]$ he commission, co- 
commentary suggests that entrusting the interests of third-party and independent candidates to the Democratic and Republican parties is akin to asking the fox to guard the henhouse. ${ }^{192}$ This concern about major-party manipulation would arise even if-as in the National Presidential Debates Act-it were not left to the parties to set the criteria for inclusion in the debates. ${ }^{193}$ The Democratic

chaired by the two Parties' Chairmen, would by its makeup be inclined to exclude third-party challengers."); Goodman, supra note 5, at 56 ("[T] control over the most important 60-minute sequences in the political process is bad for folks in the living room."); Knight, supra note 114 (quoting Martin Lee, analyst from the media watchdog group Fairness and Accuracy in Reporting (FAIR), claiming that major-party control of the debate process means that issues "are not going to be raised in a way that are [sic] going to question the two-party consensus"); Mark Sullivan, Dateline: Washington, States News Serv., Nov. 26, 1985, available in LEXIS, Nexis Library, SNS File (quoting Dorothy S. Ridings, Chairwoman of the League of Women Voters, who queries: " $[t]$ he moment conflicting demands by the candidates surfaced, who would fill the role of a third party honest broker to resolve the conflicts?"). But see JAMIESON \& BIRDSELL, supra note 8, at 213 (supporting party sponsorship of debates because it best insures participation by major-party nominees); MrTCHELL, supra note 5, at 57 (stating that responsibility for the debates would not be inconsistent with the parties' present role, which already includes facilitating the presentation of the candidates to the public through the provision of advice, personnel, and facts); How to Ensure Presidential Debates, supra note 8, at 15 (arguing that party sponsorship is advantageous because the parties' close relationship with the candidates enables them to accomplish most of the debate planning in advance of the campaign).

192 See, e.g., Debates and Public Service, supra note 113, at 15 (suggesting that the Commission would be inclined to give third-party candidates short shrift); How to Ensutre Presidential Debates, supra note 8, at 15 (noting that the inclusion of third-party and independent candidates poses especially difficult problems if the major parties are sponsors of the debates); Sullivan, supra note 191 ("[M]aking the two parties responsible would effectively rule out appearances of strong independent candidates and make it unlikely that debates would be held."). But see Who'll Protect the John Andersons?, supra note 114, at A30 (arguing that CPD sponsorship would be no worse for third-party candidates than would the nonpartisan sponsorship of a group like the League of Women Voters, which dropped Anderson in order to insure a CarterReagan debate in 1980).

${ }^{193}$ Allowing major parties to choose criteria for inclusion seems naive, since they have little incentive to voluntarily include minor-party candidates. They lack such incentive because conventional wisdom suggests that a lesser-known political figure invariably gains credibility by sharing the political spotlight of his better-known competitor. See MrTCHELl, supra note 5, at 72 ("Even Stephen Douglas recognized before his first debate with Lincoln that, as the better known of the two and the favorite, he had little to gain."); Wicker, supra note 7, at A23 ("Why . . give a lessfamiliar opponent an equal platform before a large television audience? Having done that was one of the prime reasons Richard Nixon lost the Presidency to John Kennedy in 1960."). "[E]very debate carries a risk, whether a slip of the tongue, lack of ease, an unfortunate mannerism, or the danger of being deflated by an opponent's oneliner." MacNeil/Lehrer Newshour, supra note 7 (remarks of Roger Mudd). Thus, incumbents have traditionally been reluctant to debate their chief challengers, let 
and Republican parties are ipso facto partisan, and their leadership is primarily concerned with "looking for ways to enhance the relevance of their own institutions on the political scene. ${ }^{n 194}$ If this enhancement is achieved by determinations about debate substance and format that trammel the interests of third-party candidates, there is no reason to assume that the major parties would be deterred by considerations of equity and fair play. ${ }^{195}$

Events leading up to the 1992 debates, however, suggest an ironic truth about the CPD: rather than functioning as an accomplice of the major-party candidates, it has been relegated to the victim role formerly assumed by the League, a toothless patsy prostrate before the beck and whim of the Democratic and Republican campaigns. Not until October did the two major parties reach agreement about the debates, and such accord came only after weeks of posturing over details, and without any CPD input. ${ }^{196}$ Four months earlier, in June 1992, the CPD had announced a debate schedule that Bush rejected, resulting in Clinton's solo appearance at the first two debate sites. ${ }^{197}$ The two campaigns did not even announce that the CPD was to sponsor the debates until October 2, 1992. ${ }^{198}$ Once the debates were announced, and despite the CPD's intent to avoid a process whereby either side could blackball journalists deemed unfriendly or unfair, the two campaigns insisted on both a say in the choice of questioners and "veto authority." 199 As White House spokesman Marlin Fitzwater

alone minor-party candidates who pose little threat. Major-party candidates, with little to gain from debates against lesser-known opponents and much to lose, are heedful of the maxim: "Never debate down. Always debate up." Id. (quoting former President Richard Nixon, who refused to debate either Humphrey in 1968 or McGovern in 1972). But see LANOUE \& SCHROTT, supra note 5, at 37 (suggesting that because Reagan lost nothing by accepting Mondale's challenge to debate in 1984, it can no longer be argued with certainty that presidential debates invariably help the lesser-known candidate). Perot's presence on the 1992 debates seemed neither to help nor hinder one of the two major-party candidates vis-à-vis the other. Cf. supra note 116.

${ }^{194}$ Debates and Public Service, supra note 113 , at 15.

195 At the founding of the CPD, its chairmen offered a joint statement in which they expressed the belief that the CPD would enable them better to fulfill their party responsibilities. See Debates Gave Voters, supra note 4, at 3.

${ }^{196}$ See Michael Kranish, Accord on Three Debates Reported, BosTon GLOBE, Oct. 2, 1992 , at 1 .

197 See id.

198 See Richard L. Berke, Bush and Clinton Agree on Debates; Plan to Ask Perot, N.Y. Times, Oct. 3, 1992, at 1.

${ }^{199}$ See Howard Kurtz, Journalists Posing Debate Questions to be Chosen by Bush, Clinton, WASH. POST, Oct. 4, 1992, at A23; Lori Santos, Debate Panel Selected for Sunday 
admitted: "The commission is not in control. We are-the two" candidates. $" 200$

CPD sponsorship of the debates may thus present third-party and independent candidates with a double-edged sword: a bipartisan debate sponsor, and major-party candidates who refuse to be guided by "bipartisan" determinations not deemed to maximize their individual interests.

Finally, the Democracy in Presidential Debates Act, recently introduced by Representative Timothy Penny, is the most promising of the three bills because it intentionally obviates the handicaps the other two proposals pose for minor-party or independent candidates. ${ }^{201}$ First, Penny's bill would restrict debate sponsorship to nonpartisan entities, a criterion that would scuttle the CPD's controversial role. ${ }^{202}$ The legislation would also oblige all candidates receiving primary federal matching funds and qualifying for the ballot in at least forty states-either as their party's nominee or

Face-Off, UPI, Oct. 8, 1992, available in LEXIS, Nexis Library, UPI File.

${ }^{200}$ Leslie Phillips, Debates: Big Efforh, But Little Progress, USA TODAY, Oct. 1, 1992, at 12A. The CPD's capitulation to the two campaigns in 1992 was reminiscent of its behavior four years earlier. In 1988 the CPD acceded to all demands made by the two campaigns: both campaigns chose the moderators and panelists, no follow-up questions were permitted, both sides packed the audience with supporters, and the Dukakis camp even succeeded in getting a ramp built to make its candidate look taller. See id.

201 See H.R. 791, 102d Cong., 1st Sess. (1991). Bill sponsor Rep. Penny has explained that the legislation "sets objective criteria for the inclusion of significant national independent and minor party candidates. . . . In the interests of fairness and free and open dialog[ue], all significant candidates who meet the stringent criteria set forth in this legislation must be included in the debates." 137 CONG. REC. E397 (daily ed. Feb 4., 1991). As of October 5, 1992, the Democracy in Presidential Debates Act had attracted 28 co-sponsors, 27 of whom were Democrats. See H.R. 791: Democracy in Presidential Debates Act of 1991, Bill Tracking Rep., Oct. 5, 1992, available in LEXIS, Legis Library, Bltrck File.

202 See H.R. 791, 102d Cong., 1st Sess. \$ 3 (1991); 137 CONG. REC. E398 (daily ed. Feb. 4, 1991) (remarks of Rep. Penny) (noting that a nonpartisan sponsor will "guarantee[] that the format of the debates will be in the voters' interests, not the candidates' interests"). Sponsor Rep. Penny aptly summarized the merits of legislative inclusion of third-party candidates in an institutionalized debate format: more robust political dialogue, greater voter participation, the democratization of a major element of the campaign process and, in short, better debates. See id.

Democratic Sen. Paul Wellstone of Minnesota is sponsoring a substantially similar sister bill in the Senate. See S. 2213, 102d Cong., 2d Sess. (1992). Wellstone's bill provides for three debates rather than Penny's two, and links the obligation to participate in debates to the receipt of any federal general election campaign funding, rather than merely the receipt of matching funds. See id. § 2. Because Wellstone's proposal is similar in many respects to Rep. Penny's legislation, it does not merit detailed separate treatment in this Comment. 
as an independent candidate-to participate in debates organized by the nonpartisan sponsor. ${ }^{203}$ These inclusion criteria are truly objective, and carefully calibrated to capture only significant, national third-party or independent candidates. Pursuant to these criteria, only two non-major-party candidates would have been invited to the 1988 debates, ${ }^{204}$ and two would have been invited in $1992 .{ }^{205}$ With the addition of the major party candidates, the Democracy in Presidential Debates Act would have thus comprehended four debate participants in both 1988 and 1992, a number that seems eminently practicable.

This Comment now examines the various criteria that have been proposed for determining who should be included in nationally televised debates. Most of these standards pose special problems for non-major-party aspirants. This section will conclude with a suggestion for adopting those criteria that will maximize participation in televised presidential debates by significant national thirdparty or independent candidates, while still selectively restricting access to these fora. Since Representative Penny's Democracy in Presidential Debates Act contains such criteria, this Comment will urge its adoption.

\section{Toward Objective Selection Criteria}

In 1980, the League of Women Voters established threshold requirements for candidates to participate on the nationally televised debates. ${ }^{206}$ The standards included: meeting constitutional age and citizenship requirements; gaining nomination on

203 See H.R. 791, 102d Cong., 1st Sess. § 3(c)(1), (2). The financial qualifications can also be met if the candidate "has raised not less than $\$ 500,000$ on or after January 1 of the calendar year immediately preceding the calendar year of the Presidential election." Id. § 3(c)(2)(A), (B).

${ }^{204}$ See Spotts, supra note 171, at 576-77 (noting that the Libertarian Party's Ron Paul and the New Alliance Party's Lenora Fulani would have met the bill's criteria).

${ }^{205}$ In 1992, such criteria would have allowed the participation of Fulani and Libertarian candidate Andre Marrou. Ross Perot, ironically, would not have qualified for the debates under Penny's bill, since he neither received public funding, nor raised the necessary $\$ 500,000$ within the stated time period. See supra note 203 . Perot's technical failure to meet the inclusion criteria can be attributed to his anomalous candidacy, and his eleventh-hour declaration as a presidential aspirant. The spirit of Penny's bill, however, would clearly embrace a Ross Perot. His candidacy should thus be instructive, serving to guide those redrafting the bill before its eventual reintroduction by illustrating a possible oversight in the financial eligibility provision.

${ }_{206}$ For a description of the League's 1987 primary election debate criteria, see Barmann, supra note 16, at 451 n.50. 
state ballots sufficient to have a mathematical possibility of winning in the Electoral College; and demonstrating sufficient voter interest and support, which one could accomplish either by virtue of a major party's nomination, or a fifteen percent support level in several national public opinion polls. ${ }^{207}$

The League's focus on potential for electoral victory was unduly restrictive. Framing the chief requirement for inclusion in terms of statistical likelihood of attaining the presidency is tantamount to an admission that the principal function of debates is to showcase the only two candidates who traditionally have a chance of winning: the Democratic and Republican nominees. Such a view does not acknowledge the potential debates hold for enriching the national dialogue, a potential that could best be exploited by the presence of significant third-party or independent candidates who bring alternative viewpoints to bear on the major issues of the day. Use of polls is similarly flawed; they should be avoided because they are at once unreliable and subject to manipulation for the benefit of major parties. ${ }^{208}$

In 1988 and 1992, the CPD utilized criteria whose focus on potential for electoral victory was even more restrictive, and substantially more subjective, than that of the League. ${ }^{209}$ The

207 See Dunn, supra note 68, at 652 n.140 (quoting League of Women Voters Education Fund Criterion Statement, Aug. 10, 1980). Only five minor-party candidates would have met these criteria in the twentieth century: John Anderson in 1980; George Wallace in 1968; Henry Wallace in 1948; Robert LaFollette in 1924; and Theodore Roosevelt in 1912. See id. at 652 n.141. Ross Perot would not have met these criteria, since his support had dropped into single digits by the time he reannounced his bid for the presidency. See Robin Toner, Poll Finds Hostility to Perot and No Basic Shift in Race, N.Y. Times, Oct. 6, 1992, at A1.

208 See Bonafede, supra note 71 , at 1898 ("Pollsters are the first to admit that voter surveys are little more than snapshots of public attitudes and are vulnerable to immediate change. Polling statistics can be manipulated, and many office seekers are not above using them capriciously"). The League of Women Voters' actions in 1980 serve as a classic example of the misuse of polling statistics. The League utilized a numerical threshold: a candidate with $15 \%$ support in a national opinion poll was invited to the debate, provided she had satisfied other criteria. See Who'll Protect the John Andersons?, supra note 114, at A30. When Anderson's support waned, the League refused to allow him to participate in the second debate, despite his national stature. See Cooper, supra note 99, at 1885 . The 20th-Century Fund Task Force rejected the use of putatively objective "criteria" such as polls in determining the "significan[ce]" of a given candidate. See How to Ensure Presidential Debates, supra note 8 , at 15 ('[The League of Women Voters' use of polls] adds to the artifice of presidential debates because it gives an inherently subjective and political judgment a patina of science and objectivity."). The Task Force concluded that criteria for determining which qualifications make a "significant" candidate could not be fixed in advance. See id.

${ }^{209}$ See Commission on Presidential Debates, Candidate Selection Criteria 
CPD's policy was to extend automatic debate invitations to the two major-party candidates, since the continuous monopoly on the presidency enjoyed by the two major parties for over a century is indicative of an "historical prominence and sustained voter interest" warranting automatic inclusion. ${ }^{210}$ Though one cannot quibble with this truism, the subsequent provision declaring that "any [other] candidate with a realistic chance of winning the general election"211 shall be granted an invitation is problematic. Use of amorphous standards-such as "realistic chance of winning" or a "viable" candidacy-should be avoided, for by focusing on potential for electoral success, these standards are simply inadequate for safeguarding third-party interests.

In an effort to fill out the content of its "realistic chance" benchmark, the CPD elucidated a host of criteria to guide its determinations of who merits an invitation to the debates. ${ }^{212}$ These criteria reveal how the deck is stacked against minor candidates, for they seem to have been chosen so as to guarantee that no one can fulfill them. ${ }^{213}$ The criteria require candidates to demonstrate: (1) evidence of a national organization; ${ }^{214}$ (2) signs of national competitiveness and newsworthiness; ${ }^{215}$ and (3) indica-

FOR 1992 GENERAL ELECTION DEBATE PARTICIPATION (1992) [hereinafter CANDIDATE SELECTION CRITERIA] (on file with author). The CPD's more detailed guidelines were developed with the help of an advisory committee chaired by Harvard's Richard Neustadt. Because the 1992 criteria were similar in most respects to the 1988 criteria, albeit more comprehensive, this Comment will refer only to the 1992 criteria.

${ }^{210} I d$. at 1.

211 Id. This "realistic chance" touchstone means that the candidate's name must be present on ballots in enough states to win 270 electoral votes, the constitutional minimum a presidential aspirant needs to be elected.

212 See id. at $2-4$.

${ }^{213}$ See, e.g., Fulani II, 935 F.2d 1324, 1326 (D.C. Cir. 1991) (reporting Lenora Fulani's contention that "the CPD is engaging in a program of political misinformation, perpetuating bipartisan, rather than nonpartisan, political debates"). Barmann argues that "realistic chance" criteria function as "unreasonable restriction[s] that serve[] the major parties at the expense of the educational value of the debates. ... Not even John Anderson had a 'realistic chance of being elected' in 1980." Barmann, supra note 16, at 453. If these criteria were diligently followed, even Ross Perot, a 1992 debate participant, would have had no such "realistic chance." See infra note 225.

214 See CANDIDATE SELECTION CRITERIA, supra note 209, at 2-3. The factors to be considered for national organization include: placement on the ballot in enough states to have a mathematical chance of obtaining an Electoral College majority; organization in a majority of congressional districts in those states; declaration of a third-party or independent candidacy before the major party conventions or primaries; and eligibility for campaign funds from the Federal Election Commission. Id.

215 See id. at 3. Factors to be considered in this regard include the professional 
tors of national public enthusiasm or concern. ${ }^{216}$ The considerable detail the CPD relies on, however, cannot obscure the twofold problem with the criteria: they are inherently subjective, and the CPD applies them in admittedly subjective fashion. ${ }^{217}$

The criteria, in fact, are skewed to foster exclusion at every turn. By requiring eligibility for matching funds from the FEC, for example, the "national organization" criterion of the CPD is more restrictive than the eligibility requirements contained in Rep. Penny's bill. 218 As for "national newsworthiness and competitiveness," the factors used in that determination disadvantage minor-party candidates by relying on professional media opinions and column inches of coverage. ${ }^{219}$ As a conservative institution essentially interested in preserving the status quo, ${ }^{220}$ the media

opinions of the Washington bureau chiefs of major newspapers, news magazines and broadcast networks; the opinions of professional campaign managers and pollsters not currently employed by the two major-party candidates; the opinions of electoral politics specialists at major universities and research centers; column inches on newspaper front pages and exposure on network telecasts in comparison with majorparty candidates; and published views of prominent political commentators. See id.

216 See id. at 3-4. Factors used for this determination are the findings of "significant" public opinion polls and reported attendance at meetings and rallies across the country in comparison with the Democratic and Republican candidates. See id. at 4.

217 The CPD states that the "nonpartisan criteria" upon which it relies for selection of non-major party candidates "contemplate no quantitative threshold that triggers automatic inclusion in a Commission-sponsored debate." Id. at 1. Applying such criteria, apparently, the CPD determines which third-party or independent candidates have a "more than theoretical" possibility of being elected.

218 See supra notes 201-05 and accompanying text. Rep. Penny's bill offers an alternative to qualifying for matching funds: raising at least $\$ 500,000$ on or after Jan. 1 of the calendar year immediately preceding the calendar year of the presidential election. See supra note 203. The Libertarian Party is ideologically opposed to receiving federal matching funds; therefore, its candidate Andre Marrou would fail this CPD criterion, but qualify for debate inclusion under Rep. Penny's bill. See Spotts, supra note 171 , at 567.

Further, another factor weighed in assessing existence of a "national organiza-

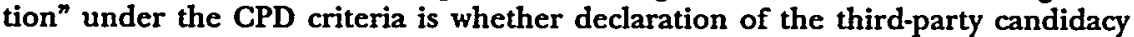
occurred prior to the major-party convention. See CANDIDATE SELECTION CRITERIA, supra note 209, at 2. This factor could be invoked against a third-party candidate who threatens to steal the thunder from the national conventions by a late announcement of her candidacy. It also cuts against Ross Perot, whose candidacy was announced a little more than a month before the 1992 election.

219 See supra note 215.

220 See generally BEN H. BAGDIKIAN, THE MEDIA MONOPOLY (3d ed. 1990). Bagdikian argues that the national political dialogue has become sterile in part because of the media's failure to reflect "the full range of ideas and programs that exist in American thinking and expertise." Id. at 237. He attributes this failure to the concentration of media power in the hands of media corporations who share a uniformity of outlook. See id. at 223; see also ROSENSTONE ET AL., supra note 21, at 37. 
naturally expends most of its ink on major-party candidates. Additionally, the media's predilection for presenting the presidential campaign as a horse race bolsters a journalistic tendency to focus on only the two major-party candidates, ${ }^{221}$ while simultaneously characterizing only those candidates favored with such attention as "competitive" and "newsworthy." The media's overarching interest in who will win rather than in what the candidates are saying assures that third-party candidates will get short shrift. ${ }^{222}$ Finally, "public enthusiasm or concern" is also deficient as a criterion, primarily because it resorts to polls. ${ }^{223}$

In sum, the CPD selection criteria fail to give non-major party candidates a fair shake. The criteria are substantively subjective, and are applied subjectively; they depend upon factors catering to the establishment, standards pursuant to which minor-party candidates cannot succeed. Moreover, they are applied by a majorparty organization powerless to hold sway over its own candidates, ${ }^{224}$ as evidenced by the hypocrisy of the decision to include Ross Perot in the 1992 debates. ${ }^{225}$

\footnotetext{
221 See Dunn, supra note 68, at 649.

222 See ROSENSTONE ET AL., supra note 21, at 35. As one prominent journalist put it:
}

We base [our decision] on the simple proposition that readers don't want to waste their time on someone who won't have a role in the campaign. We're not going to run a page-one spread on a fringe candidate. We don't have a multiparty system. Until we do, nobody's going to cover these candidates.

Id. (quoting James M. Perry of the Wall Street Journal).

${ }_{223}$ For a discussion of the fallacy of relying on polls, see supra note 208.

224 See supra note 196.

225 The circumstances of Perot's inclusion smacked of manipulation by the two major-party candidates. On October 2, 1992, the Bush and Clinton campaigns announced that they were inviting Ross Perot to participate in the debates. See Berke, supra note 198, at 1 . In a joint statement, the two parties explained that Perot's invitation was extended "in anticipation" of expected CPD approval. Id. In fact, Bush campaign officials claimed that "they got their way in allowing Mr. Perot to take part despite objections from the Clinton negotiators who had wanted the debate commission to decide that." Id. On October 6, 1992, Perot accepted the BushClinton invitation to appear on the debates. See Kevin Sacks, Perot Charts Poor Economy in 30-Minute TV Talk, N.Y. TIMES, Oct. 7, 1992, at A16. By Oct. 7, 1992, when the CPD finally invited Perot, the invitation thus seemed, by all accounts, the rubber stamp to a fait accompli. See No Surprise, But It's Official; Perot in Debates, Oct. 7, 1992, Reuters, available in LEXIS, Nexis Library, Reuter File (noting that the CPD's invitation to Perot was considered a "formality," since he had "already accepted the invitations of the Bush and Clinton camps which set up the ground rules for the debates").

The circumstances surrounding Perot's official invitation certainly cast doubt on the CPD's independence, but its credibility is also at issue, since Perot arguably did 
Although they can disadvantage third-party and independent candidates vis-à-vis major-party contenders, ${ }^{226}$ ballot access requirements may be a valid criterion for inclusion. Provided that a ballot-access criterion requires a candidate to gain access to the ballot in only an appreciable number of states, such a requirement can filter out the dozens of frivolous, single-issue candidates who surface during each election while preserving the interests of those few third-party or independent candidates with significant national backing. ${ }^{2: 7}$ The Democracy in Presidential Debates Act would appear to come closest to this goal by requiring qualification for the ballot in only forty states and through a careful combination of funding and ballot requirements. ${ }^{228}$ This approach recognizes

not meet the CPD's asserted "realistic chance" criteria. On October 6, 1992, a CNN correspondent reported that

one of the big concerns all along has been Perot's eligibility. The commission rulers say, "He has to have a realistic chance of winning the general election." That was a problem since so many polls showed that Perot was down in the polls. What they did is they kind of finessed that. Harvard Professor Richard Neustadt, and his adviser committee, recommended to the commission that Perot had a "remote, but real, more than theoretical chance," which they're interpreting as meaning that Perot should be in the debates.

Inside Politics: Transcript \#182 (CNN television broadcast, Oct. 6, 1992), available in LEXIS, Nexis Library, CNN File. A New York Times/CBS News poll reported that same day that only seven percent of registered voters intended to vote for Perot. See Toner, supra note 207 , at A1. This is hardly consistent with the "national public enthusiasm or concern" espoused by the CPD as a prerequisite to debate participation. See Candidate Selection Criteria, supra note 209, at 3-4. Perot also did not announce his candidacy before the major party conventions, a circumstance that should have counted against him under the CPD's "evidence of national organization" criterion. See id. at 2.

226 See supra notes $82-85$ and accompanying text. In 1988 only Bush, Dukakis, and Fulani qualified for all 51 ballots. See Barmann, supra note 16, at 454. In 1992, only Bush, Clinton, Marrou, and Perot were on 51 ballots. See FEC NEWs RELEASE, supra note 84 , at $1-3$.

${ }^{227}$ In 1988 , about 280 people filed statements with the FEC indicating that they considered themselves to be presidential candidates. See Fulani I, 882 F.2d 621, 625 (2d Cir. 1989).

${ }^{228}$ See H.R. 791, 102d Cong., 1st Sess. § 3(c) (1991); see also Barmann, supra note 16, at 465 ("Keeping the threshold low enough so that not all fifty states have to be covered recognizes that third-party candidates are handicapped in many ways."); supra notes 201-05 and accompanying text. Requiring a candidate to leap ballot access hurdles in even 40 states is still a formidable task. As of September 28th, 1992, only four third-party presidential candidates were on at least 20 ballots: Andre Marrou of the Libertarian Party (in 50 states and the District of Columbia), John Hagelin of the Natural Law Party (28 states and the District of Columbia), Lenora Fulani of the New Alliance Party (39 states and the District of Columbia), and, of course, Ross Perot (50 states and the District of Columbia). See FEC NEWS RELEASE, supra note 84, at 1-3. 
that third-party and independent candidates are not similarly situated with major-party candidates. The two-pronged test would permit inclusion in presidential debates of those candidates who are significant and national, and who can contribute to the national dialogue, but who may not have a substantial likelihood of winning the election. Conscientious application of Rep. Penny's judicious criteria will enable significant third-party and independent candidates to play a role in these debates without diluting these fora to such an extent that they cease to be useful arenas for discussion. In addition, such criteria will avert the problems of exclusion. ${ }^{229}$

\section{CONCLUSION}

The presidential election of 1992 bore witness to a "remarkable national sense of voter disgust with politics as usual". ${ }^{230}$ An enduring faith in the electoral process underlays the electorate's cynicism, however-a faith dramatized by a continuing quest for ways to enhance both the meaning and informative value the process holds for individual voters, and its capacity to grapple with important issues. This desire to make of the process something better found wing in the burgeoning twin interests in televised debates and non-major party candidates. In 1992, televised debates came of age: more debates were held than ever, and record audiences tuned in to listen to what the candidates had to say. ${ }^{231}$ The electorate also voiced its desire for alternative viewpoints in ringing terms, spurring an independent candidate to the strongest showing of any non-major-party nominee in eighty years.

Given this expressed desire for both televised debates and third parties, any proposal that could improve either merits serious consideration; a proposal that would simultaneously strengthen both while enhancing the integrity of the political process, galvanizing

229 See MrTCHELL, supra note 5, at 83-84 (" $[$ E]xcluding [these candidates] from such television exposure as the debates is unfair, is likely to sound the death knell of dissent, and, even if our political system is indeed a two-party system, is likely to make the Republican and Democratic parties the two parties."). Rep. Penny's bill has also been endorsed by several other commentators. See Spotts, supra note 171, at 579-80 (arguing that the bill would assure that "voters could rely on televised debates for a more substantive view of the candidates and their proposals" and that "voters will receive information on significant third party candidates that may better represent their concerns."); Kovaka \& Block, supra note 183, at 7-8 (position paper, co-authored by attorney for Lenora Fulani, arguing that the bill "will promote more speech, more viewpoints, and a more level playing field").

${ }^{230}$ Firestone, supra note 31, at 29.

231 See Kubasik, supra note 5, at 6. 
voter interest, reinforcing the egalitarian ideal of our democracy, and improving the national dialogue, demands adoption. The legislative institutionalization of debates is such a proposal. Yet all institutionalization proposals are not created equal. Plans that would apply artificially high or overly subjective criteria for thirdparty or independent candidate inclusion, and those that would perpetuate bipartisan sponsorship of debates, must be rejected as self-defeating. Alternatively, this Comment urges the adoption of Rep. Timothy Penny's Democracy in Presidential Debates Act, which obviates the problems of other proposals and promises to nurture both debates and third parties.

While the benefits of such reform will redound to the entire polity, to Republicans and Democrats alike, institutionalization does not offer the major parties profit without pain. Any incursion by a third-party or independent candidate will only come at the expense of the two-party symbiosis that has nurtured and sustained the major parties' virtual monopoly on access to the political process. The inclusion of several additional candidates in the debates, however, poses little threat to the two-party hegemony. Rather, the chief expense will be the costs associated with increased accountability, and the increased efforts needed for consensus building. The desire to reduce political costs, however, should not take precedence over the merits of inclusion, over those tangible and intangible benefits better debates and better third parties can provide to all. 
